\title{
Trends in Widely Used Catalysts for Fatty Acid Methyl Esters (FAME) Production: A Review
}

\author{
Shafaq Nisar ${ }^{1}$, Muhammad Asif Hanif ${ }^{1, *}$, Umer Rashid ${ }^{2, * \mathbb{D}}$, Asma Hanif ${ }^{3}$, Muhammad Nadeem Akhtar ${ }^{4}(\mathbb{D}$ \\ and Chawalit Ngamcharussrivichai ${ }^{5,6}$
}

check for updates

Citation: Nisar, S.; Hanif, M.A.; Rashid, U.; Hanif, A.; Akhtar, M.N.; Ngamcharussrivichai, C. Trends in Widely Used Catalysts for Fatty Acid Methyl Esters (FAME) Production: A Review. Catalysts 2021, 11, 1085. https: / / doi.org/10.3390/ catal11091085

Academic Editors: José María Encinar Martín and Sergio Nogales Delgado

Received: 11 August 2021

Accepted: 1 September 2021

Published: 9 September 2021

Publisher's Note: MDPI stays neutral with regard to jurisdictional claims in published maps and institutional affiliations.

Copyright: (c) 2021 by the authors. Licensee MDPI, Basel, Switzerland. This article is an open access article distributed under the terms and conditions of the Creative Commons Attribution (CC BY) license (https:// creativecommons.org/licenses/by/ $4.0 /)$.
1 Nano and Biomaterials Laboratory, Department of Chemistry, University of Agriculture, Faislabad 38040, Pakistan; shafaqnisar12@gmail.com

2 Institute of Advanced Technology, Universiti Putra Malaysia, Serdang 43400, Malaysia

3 Department of Chemistry, Government College Women University Faisalabad (GCWUF), Faisalabad 38000, Pakistan; asmarana_hanif@yahoo.com

4 Division of Inorganic Chemistry, Institute of Chemistry, Baghdad-ul-Jadeed Campus, The Islamia University of Bahawalpur, Bahawalpur 63100, Pakistan; nadeemchem@yahoo.com

5 Center of Excellence in Catalysis for Bioenergy and Renewable Chemicals (CBRC), Faculty of Science, Chulalongkorn University, Bangkok 10330, Thailand; chawalit.ng@chula.ac.th

6 Center of Excellence on Petrochemical and Materials Technology (PETROMAT), Chulalongkorn University, Bangkok 10330, Thailand

* Correspondence: drmuhammadasifhanif@gmail.com (M.A.H.); umer.rashid@upm.edu.my or dr.umer.rashid@gmail.com (U.R.); Tel.: +60-3-9769-7393 (U.R.)

\begin{abstract}
The effective transesterification process to produce fatty acid methyl esters (FAME) requires the use of low-cost, less corrosive, environmentally friendly and effective catalysts. Currently, worldwide biodiesel production revolves around the use of alkaline and acidic catalysts employed in heterogeneous and homogeneous phases. Homogeneous catalysts (soluble catalysts) for FAME production have been widespread for a while, but solid catalysts (heterogeneous catalysts) are a newer development for FAME production. The rate of reaction is much increased when homogeneous basic catalysts are used, but the main drawback is the cost of the process which arises due to the separation of catalysts from the reaction media after product formation. A promising field for catalytic biodiesel production is the use of heteropoly acids (HPAs) and polyoxometalate compounds. The flexibility of their structures and super acidic properties can be enhanced by incorporation of polyoxometalate anions into the complex proton acids. This pseudo liquid phase makes it possible for nearly all mobile protons to take part in the catalysis process. Carbonaceous materials which are obtained after sulfonation show promising catalytic activity towards the transesterification process. Another promising heterogeneous acid catalyst used for FAME production is vanadium phosphate. Furthermore, biocatalysts are receiving attention for large-scale FAME production in which lipase is the most common one used successfully This review critically describes the most important homogeneous and heterogeneous catalysts used in the current FAME production, with future directions for their use.
\end{abstract}

Keywords: catalysis; FAME; zeolites; montmorillonite; heteropoly acids; polyoxometalates

\section{Introduction}

We rely on fossil fuels to run our vehicles, heat our homes, for manufacturing and the power industry, and to provide us with electricity. In 2010, according to an estimate by the Environmental Protection Agency (EPA), the burning of fossil fuels caused 79 percent of U.S. greenhouse gas emissions [1]. However, emissions of greenhouse gases are highly unevenly distributed around the countries of the world, with the top ten greenhouse gases emitting countries accounting for more than $60 \%$ of the total emissions. Three countries (China, the USA and India) are the largest contributors, with 21.1\%, 14.1 and 5.2\% emissions, respectively [2]. These gases shield the planet, and that is why these gases could lead to 
potentially calamitous changes in the climate of the earth. Environmental pollution and oil depletion have become distressing situations which require a search for alternative ways to generate energy. Renewable energy can be regarded as an additive to fossils energies. The calorific value of vegetable oil is comparable to that of diesel, and so researchers determined that vegetable oils hold promise as replacement fuels for modern diesel engines. However, there are some physical properties of vegetable oils which are unfavorable, and these properties limit the use of vegetable oil in direct injection diesel engines, predominantly their viscosity, which is almost 11-17 times greater than the viscosity of diesel fuel. In order to reduce the viscosity of vegetable oils, different methodologies can be applied: the dilution of 75 parts diesel fuel with 25 parts vegetable oil, pyrolysis, microemulsions, catalytic cracking, and transesterification with alcohol to produce fatty acid alkyl esters, usually known as biodiesel fuel [3].

Biodiesel is a renewable, non-toxic and biodegradable fuel that can be formed from range of renewable and organic raw material including waste or fresh vegetable oils, oilseed plants, and animal fats [4,5]. According to the definition provided by the American Society for Testing and Materials (ASTM), biodiesel is a fuel consisting of "long chain fatty acids of mono-alkyl esters derived from renewable fatty raw material such as animals fats or vegetable oils" [6]. Biodiesel is preferred over other diesels because it has many advantages; it reduces greenhouse gases, has a higher combustion efficiency, increases the number of rural manufacturing jobs, and increases farmers' income. The increasing demand of biodiesel requires optimized production processes [7-15] allowing high yields, simplified operations, high production capacities, and the use of more economic feedstocks such as fats and waste oils. We can use non-edible plant oils, edible plant oils, microalgae and animal fats as feedstocks for biodiesel production [14]. Non-edible oils are not appropriate for human consumption because of the presence of toxic constituents in the oils. Hence, nonedible oils are considered an auspicious way to produce biodiesel as a raw material. The most important non-edible oil plants are neem, karanja, mahua, tobacco, jatropha, rubber, castor, sea mango and cotton. All over the world biodiesel has been primarily produced on a large scale from the edible oils ( $>95 \%)$, which are easily available from the agricultural industry. Presently, biodiesel is mainly prepared from soybean in the USA, rapeseed in Canada, palm in Southeast Asia, and rapeseed and sunflower in Europe [16,17]. In recent years, microalgae as a raw material for biodiesel production have been studied extensively. Microalgae convert $\mathrm{CO}_{2}$, water, and sunlight to algal biomass as they are photosynthetic organisms. The production of food and biofuels is largely dependent upon algae biomass. Animal fats which are used for biodiesel production include white grease, tallow, chicken fat and fish fat. Animal fats are frequently well-priced for the conversion into biodiesel, which is why these fats often offer economic advantages over plant crops in the production of biodiesel. Animal fat would never successfully meet the fuel demand of the entire world because there is an inadequate amount of these oils available [4]. Nowadays, commercial biodiesel is produced through liquid base-catalyzed transesterification of triacylglyceride (TAG) with low carbon chain alcohols into fatty acid methyl esters (FAMEs) which produce biodiesel with a valuable byproduct: glycerol. However, higher carbon chain alcohols can also be used for FAME production, but the difficulties involving the separation of the heavier product (FAME) from unreacted alcohol and glycerol, remain challenging [9,18-21].

As described earlier, there are several methods for FAME production, but the most appropriate and common method is the transesterification method. Transesterification requires catalysts for a more successful FAME production in a shorter time [22]. In the present review, different catalysts, which can be used efficiently to produce biodiesel, are discussed in detail along with their merits and demerits. In general, catalysts that can be used for producing biodiesel are divided into three groups: acidic, alkaline and biocatalysts. Alkaline catalysts exhibit a better performance compared with other catalysts, but there are subsequent limitations depending on which other types of catalysts (such as acid and enzymatic) are introduced. These problems include: the postreaction treatment for the separation of catalysts from the reaction media after completion of the reaction, 
high energy demand, difficulty in glycerol recovery after completion of the reaction, and interferences caused by the presence of water and free fatty acids (FFA) during the reaction [23]. However, there are also some disadvantages of acid-catalyzed transesterification. The rate of reaction for this process is very slow compared to alkali-catalyzed transesterification. The efficiency of ester conversion is powerfully affected by the alcohol-to-oil molar ratio. In acid-catalyzed transesterification, a higher molar ratio is required, compared to alkali-catalyzed transesterification. At $25^{\circ} \mathrm{C}$ (room temperature), the process is very slow and poor ester conversion is attained. However, with the increase in the amount of acid catalyst, the completion of ester production increases. The presence of water content in the oil strongly inhibits the ester conversion. If the water content is $>0.5 \%$ and FFAs are $>5 \%$, the conversion rate of ester may fall below $90 \%$ [24]. Lipases are categorized as enzymes that can be introduced as catalysts in FAME production in the transesterification reaction, a process which takes a long time. Lipase enzymes have many advantages; the residue of these constituents is renewable and they showed a higher thermostability (higher catalytic activity under high temperatures) [25]. However, lipase enzymes also have some disadvantages, such as high cost, prolonging of the reaction time and failure to steadily support reactive species [26]. Alkaline and acidic catalysts are classified into two groups: homogeneous and heterogeneous catalysts. The current review critically describes the advantages and disadvantages related to these catalysts and the solutions to the issues they cause.

\section{Homogeneous Catalysts}

Catalysts play a vital role in the transesterification process. Both the amount and type of catalyst affect the rate of reaction and conversion efficiency. In Table 1, the effect of various catalysts on the yield of FAME has been shown. Homogeneous catalysts function in the same phase as the reactants.

Table 1. Relative effectiveness of catalysts used for biodiesel production.

\begin{tabular}{|c|c|c|c|c|c|}
\hline Catalysts & Temperature $\left({ }^{\circ} \mathrm{C}\right)$ & Methanol-to-Oil Ratio & Feedstock & Yield $(\%)$ & References \\
\hline Sodium Hydroxide $(\mathrm{NaOH})$ & 55 & $3: 1$ & $\begin{array}{l}\text { Waste soybean } \\
\text { cooking oil }\end{array}$ & 68.5 & [27] \\
\hline $\begin{array}{l}\text { Potassium Hydroxide }(\mathrm{KOH}) \\
\text { Sodium Methoxide }\left(\mathrm{NaOCH}_{3}\right)\end{array}$ & $\begin{array}{l}50 \\
50\end{array}$ & $6: 1$ & $\begin{array}{l}\text { Jatropha seed } \\
\text { Sesamum indicum L. seed oil }\end{array}$ & $\begin{array}{c}87 \\
87.8\end{array}$ & $\begin{array}{l}{[28]} \\
{[29]}\end{array}$ \\
\hline \multicolumn{6}{|c|}{ Homogeneous acid catalysts } \\
\hline Sulfuric acid $\left(\mathrm{H}_{2} \mathrm{SO}_{4}\right)$ & 120 & $40: 1$ & $\begin{array}{l}\text { Chlorella } \\
\text { Pyrenoidosa }\end{array}$ & 92.5 & [30] \\
\hline Hydrochloric acid ( $\mathrm{HCl})$ & 100 & & Sunflower oil & 95.2 & [31] \\
\hline \multicolumn{6}{|c|}{ Heterogeneous base catalysts } \\
\hline $\mathrm{CaO}$ & 70 & 9 & Jatropha curcas oil & 93 & [32] \\
\hline $\mathrm{MgO}$ & 130 & $55: 1$ & Soybean oil & 60 & \\
\hline Zeolite X & 60 & & Sunflower & 95.1 & {$[33,34]$} \\
\hline ETS-10 zeolite & 125 & & Soybean oil & 90 & \\
\hline $\mathrm{CaO} / \mathrm{Al}_{2} \mathrm{O}_{3}$ & 65 & $12: 1$ & Palm oil & 95 & {$[34]$} \\
\hline $\begin{array}{l}\text { Mesoporous silica } \\
\text { loaded with } \mathrm{MgO}\end{array}$ & 220 & 8 & Blended vegetable Oil & 96 & {$[32]$} \\
\hline $\begin{array}{c}\mathrm{Mg}-\mathrm{Al}-\mathrm{CO}_{3} \\
\text { (Hydrotalcite) }\end{array}$ & 100 & 30 & Palm oil & 86.6 & [32] \\
\hline \multicolumn{6}{|c|}{ Heterogeneous acid catalysts } \\
\hline $\begin{array}{l}\text { Sulfated } \\
\text { Zirconia }\end{array}$ & 65 & $9: 1$ & Neem oil & 95 & {$[35]$} \\
\hline Carbon-based solid acid catalyst & 220 & $16.8: 1$ & $\begin{array}{l}\text { Waste vegetable } \\
\text { Oil }\end{array}$ & 94.8 & [36] \\
\hline $\begin{array}{l}\text { Titanium-doped amorphous zirconia } \\
\text { Sulfonated Carbon composite }\end{array}$ & $\begin{array}{c}245 \\
60\end{array}$ & $\begin{array}{l}40: 1 \\
2: 1\end{array}$ & $\begin{array}{l}\text { Rapeseed oil } \\
\text { Acetic acid }\end{array}$ & $\begin{array}{c}65 \\
74.2\end{array}$ & $\begin{array}{l}{[37]} \\
{[38]}\end{array}$ \\
\hline $\begin{array}{l}\text { Heteropoly acids and } \\
\text { Polyoxometalates }\end{array}$ & 200 & $20: 1$ & Oleic acid-Soybean Mixture & 90.4 & {$[39,40]$} \\
\hline $\begin{array}{l}\mathrm{VOPO}_{4} \cdot 2 \mathrm{H}_{2} \mathrm{O} \\
\mathrm{WO}_{3} / \mathrm{ZrO}_{2}\end{array}$ & $\begin{array}{l}150 \\
200\end{array}$ & $\begin{array}{l}1: 1 \\
20: 1\end{array}$ & $\begin{array}{l}\text { Soybean oil } \\
\text { Sunflower }\end{array}$ & $\begin{array}{l}80 \\
97\end{array}$ & $\begin{array}{l}{[41]} \\
{[42]}\end{array}$ \\
\hline
\end{tabular}

\subsection{Classification of Homogeneous Catalysts}

Homogeneous catalysts can be categorized into homogeneous base catalysts and homogeneous acid catalysts. Homogeneous base and the acid-catalyzed transesterification processes for FAME production have been extensively studied. Today, most of FAME is 
produced by the base-catalyzed transesterification reaction due to several reasons: high conversion rate (which is more than $98 \%$ in most of cases), negligible side reactions, and short reaction time. It is a low-pressure and low-temperature process, which occurs without the formation of intermediate substituents. Despite these advantages, homogeneous base catalysts have some weaknesses. The production of biodiesel from feedstocks with a high FFA content is limited. It was reported by some researchers that homogeneous base catalysts are only effective for the FAME production via the transesterification process using the feedstocks with a FFA content of less than $2 \mathrm{wt}$. \% [43]. When FFA content is $>2 \%$, the catalyst reacts with FFA to produce soap that inhibits the separation of FAME and glycerin. Hydrochloric acid $(\mathrm{HCl})$ and sulphuric acid $\left(\mathrm{H}_{2} \mathrm{SO}_{4}\right)$ are generally used as acid catalysts, particularly when the vegetable oil comprises a high amount of water and FFA. Jatropha oils and waste cooking oils (WCO) are converted into FAME using these catalysts as used these feed stocks have high concentration of FFAs. Methyl esters or ethyl esters of the fatty acids are the desired products of the reaction. Salts of alkali and glycerol are produced as by-products. Glycerol is usually used in the pharmaceutical industry and for the production of potassium fertilizer. The rate of reaction of a homogeneous acid catalyst is lower than that of a homogeneous base catalyst. These reactions require an excess of alcohol and a high temperature. Environmental problems and corrosions are also caused by liquid acids. The rate of alkali-catalyzed transesterification reaction is nearly 4000 times faster than that of acid-catalyzed transesterification reaction [44].

\subsubsection{Homogeneous Base Catalysts}

In homogenous base-catalyzed transesterification, the activity of the catalyst decreased due to the amount of it that is used by the side reactions (e.g., saponification reaction). On the other hand, with an increase in catalyst concentration, the formation of soap increased exponentially. The rate of the saponification and transesterification increased when the reaction temperature increased. Increasing the alcohol-to-oil molar ratio had a positive influence on FAME yields. Different alkaline metal alkoxides or hydroxides could be used as homogeneous catalysts for the FAME production via the transesterification process (Figure 1). When raw materials with good quality (moisture $<0.5 \mathrm{wt} . \%$ and FFA $<1 \mathrm{wt} . \%$ ) were used, the base catalysts provided good FAME yields [45].

\section{Homogeneous Base \\ catalysts
Home}

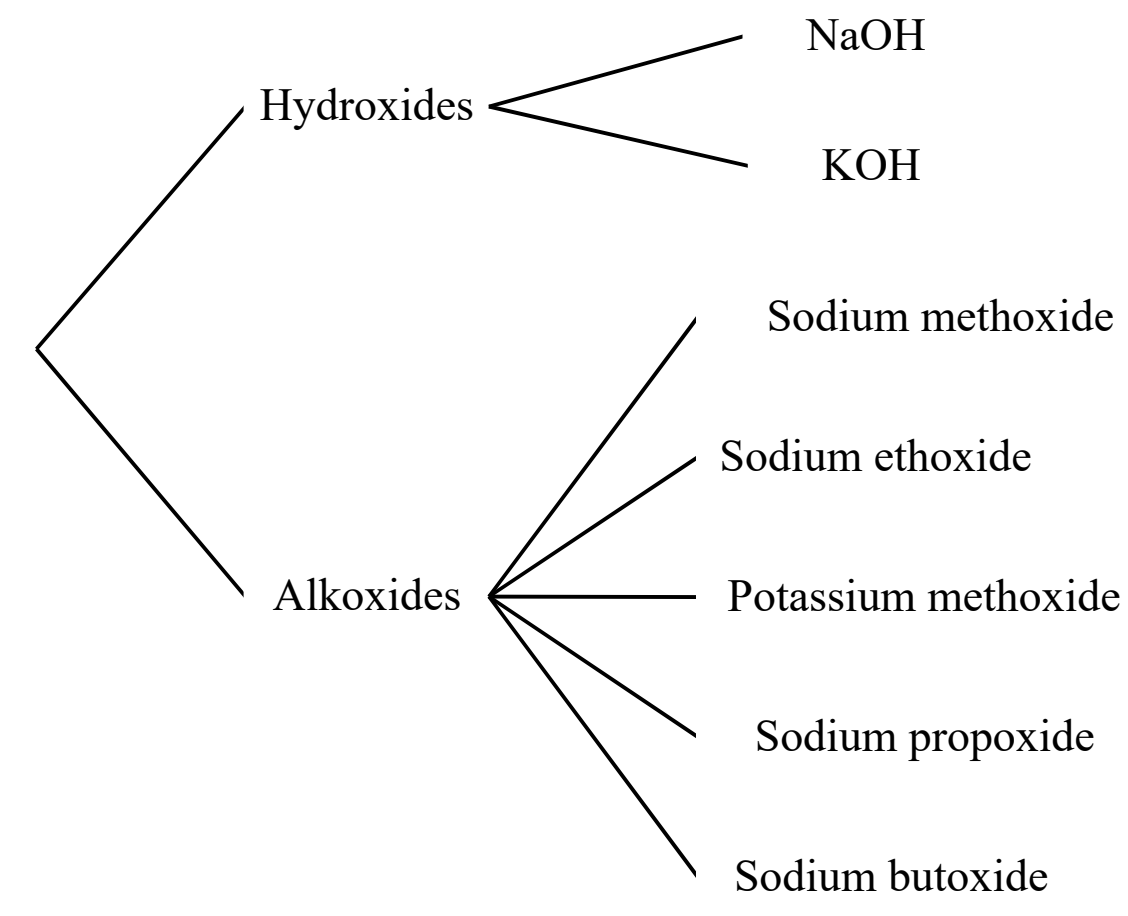

Figure 1. Classification of homogeneous base catalysts for biodiesel production. 


\section{Hydroxides}

Metal hydroxides are common homogeneous base catalysts used in industry due to their availability and low cost. Sodium hydroxide (caustic soda) and potassium hydroxide (caustic potash) are commonly used in the production of biodiesel [46]. A main side reaction in the production of biodiesel is the transformation of FFAs into soap. Soap made from sodium hydroxide $(\mathrm{NaOH})$ is solid, while soap made from potassium hydroxide $(\mathrm{KOH})$ is liquid. We prefer $\mathrm{KOH}$ over $\mathrm{NaOH}$ due to following reasons: the solubility of $\mathrm{KOH}$ is slightly higher in methanol than $\mathrm{NaOH}$; under certain conditions $\mathrm{NaOH}$ will produce glycerin (a byproduct) that can be converted into gel or even into solid; and $\mathrm{KOH}$ is heavier than $\mathrm{NaOH}$. Since we weighed our catalyst, we used less $\mathrm{NaOH}$ than $\mathrm{KOH}$. Mathematically we used 1.4 times less $\mathrm{NaOH}$ than $\mathrm{KOH}$. For the production of biodiesel, we used a base of $7 \mathrm{~g}$ per liter of $\mathrm{KOH}$ and $5 \mathrm{~g}$ per liter of $\mathrm{NaOH}$. Sodium hydroxide was relatively pure when compared to $\mathrm{KOH}$, which was usually available with almost $90 \%$ purity. Both the performance and selectivity of the transesterification process was greatly affected by the purity of the hydroxide catalysts. It was reported that good quality FAME could be produced by using waste cooking oils under optimal conditions (9:1 methanol to oil molar ratio, 1.0 wt. $\% \mathrm{NaOH}, 50{ }^{\circ} \mathrm{C}$ temperature and $90 \mathrm{~min}$ ) [47].

\section{Alkoxides}

Alkoxides are derived from $n$-alcohol radicals commonly soluble in any polar solvent such as alcohol e.g., $n$-alcohol-derived sodium alkoxides are easily soluble in alcohols $[48,49]$. So, we can use alkoxides as homogeneous base catalysts in the production of biodiesel. The major drawback of using hydroxide catalysts in alcohol solvents in the production of biodiesel, is the generation of water. Water releases hydroxide ions in the reaction media which attack the TAG and cause it to yield FFAs instead of the desired FAME product. The FFA existing in some vegetable oils react with the hydroxide base catalyst and yield soap via saponification, that also deactivates base catalysts, whereas the more costly metal alkoxides (sodium methoxide or $\mathrm{NaOCH}_{3}$ ) dissolved in alcohol yield a solution of alkoxide ions without generating water. Therefore, the $\mathrm{NaOCH}_{3}$ is frequently preferred over metal hydroxides for maintaining the rate of reaction. However, it was found that $\mathrm{NaOH}$ showed good catalytic activity than $\mathrm{NaOCH}_{3}$ but the methoxide catalysts produced a higher yield (due to no soap formation) than the hydroxide catalysts [8]. Nevertheless, the cost of $\mathrm{NaOCH}_{3}$ is pointedly higher than that of $\mathrm{NaOH}$. Due to the presence of both alkoxide and methanol in the reaction mixture, they are corrosive and flammable, and so must be controlled with caution. The rate of conversion is slowed down when a low concentration of the active methoxide catalysts is used, and the presence of hydroxides and water leads to the formation of by-products [50].

\subsubsection{Homogeneous Acid Catalysts}

In order to obtain a high yield of FAME via the acid-catalyzed transesterification process, alcohol is required in a large quantity. The most prominent advantage of using an acid catalyst over base catalyst for biodiesel production is that low temperature Furthermore, low pressure is required for their better performance [51]. Acid catalysts, usually strong acids such as hydrochloric acid, phosphoric acid, or sulfuric acid, are more favorable when the starting raw materials are rubber seed oils, waste cooking oils, and tobacco oils, which have a high FFA content because they inhibit the soap formation during the reaction. The amount of sulfuric acid catalyst varied from $0.3 \%$ to $2 \%$. These percentages (\%) are based on the oil volume used for the reaction of acid esterification, and the amount of catalyst affects the process yield [52]. However, the water content of raw materials affects the activity of acid catalysts. If the water concentration is $5 \mathrm{wt}$. \%, the reaction is completely stopped. Mostly, Brønsted acid and Lewis acid, as homogeneous acid catalysts, were used for the transesterification process (Figure 2). 


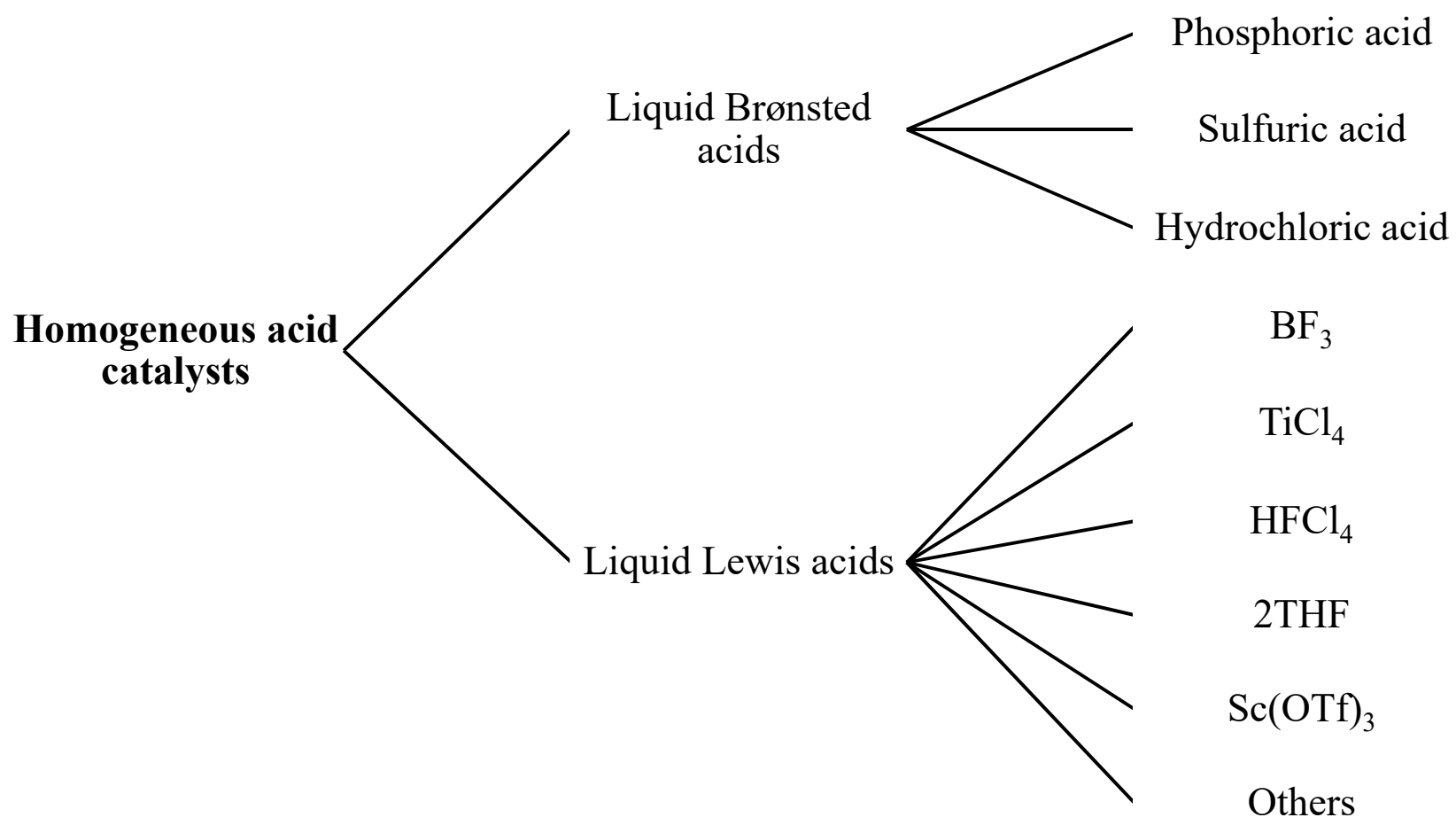

Figure 2. Classification of homogeneous acid catalysts for biodiesel production.

Brønsted Acid

Brønsted acid catalysts are frequently used for direct esterification [53]. In Brønsted acid, the sulfuric acid $\left(\mathrm{H}_{2} \mathrm{SO}_{4}\right)$ seems to be the catalyst of choice in industry. In commercial processes, $\mathrm{H}_{2} \mathrm{SO}_{4}$ is used as a catalyst for organic synthesis. Brønsted acids, like sulfonic acid and sulfuric acids, are commonly used to catalyze the transesterification reaction in order to provide a high biodiesel yield [51]. By using this type of homogeneous acid catalysts, the biodiesel production was $90 \%$ within 15 min under harsh conditions, such as a $240{ }^{\circ} \mathrm{C}$ temperature, 70 bar pressure and $1.7 \mathrm{wt}$. $\% \mathrm{H}_{2} \mathrm{SO}_{4}$. Side reactions, such as dehydration of alcohol, were also observed under such harsh conditions [54]. Hydrochloric acid $(\mathrm{HCl})$, polyphosphoric acid, soluble aryl sulfonic acids and mixtures of these catalysts were also used as homogeneous acid catalysts for the transesterification process. Even if esterification was a very old reaction, new homogeneous acid catalysts were required, which targeted the following goals. First, equimolar amounts of alcohol and FFA were used to perform the reaction, instead of an excess of one or both. Next, the reaction should be preceded at low temperatures and almost in optimum conditions. Finally, a catalyst should be removable from the reaction mixture and reusable.

Lewis Acids

Lewis acids are often preferred over Brønsted acids as there is no alcohol dehydration [55]. However, the difference between Brønsted and Lewis acids is often difficult to find in a reaction producing water. As Lewis acid compounds like zinc oxalate or $\mathrm{BF}_{3}$ form protonic acids in contact with the alcohol or water [3].

\subsection{Mechanism of Homogeneous Base-Catalyzed Reaction}

In organic reactions, the Brønsted base serves two functions. Firstly, the base accepts protons and transfers alkali metal ( $\mathrm{Na}$ or $\mathrm{K}$ ) to the reacting compound (alcohol) and hence the formation of alkoxides occurs. Secondly, basic alkoxides generate an anion which is nucleophilic in nature that can react with a carbonyl group of a carboxylic ester. In reactions of ester methanolysis by $\mathrm{NaOH}$, both functions can be observed. First of all, $\mathrm{NaOH}$ is dissolved in methanol to generate methoxide anion $\left({ }^{-} \mathrm{OCH}_{3}\right)$ by replacing its proton with 
sodium cation. Then, ${ }^{-} \mathrm{OCH}_{3}$ attacks the carboxylic ester compound via nucleophilic substitution reactions to yield a new ester compound (Figure 3).
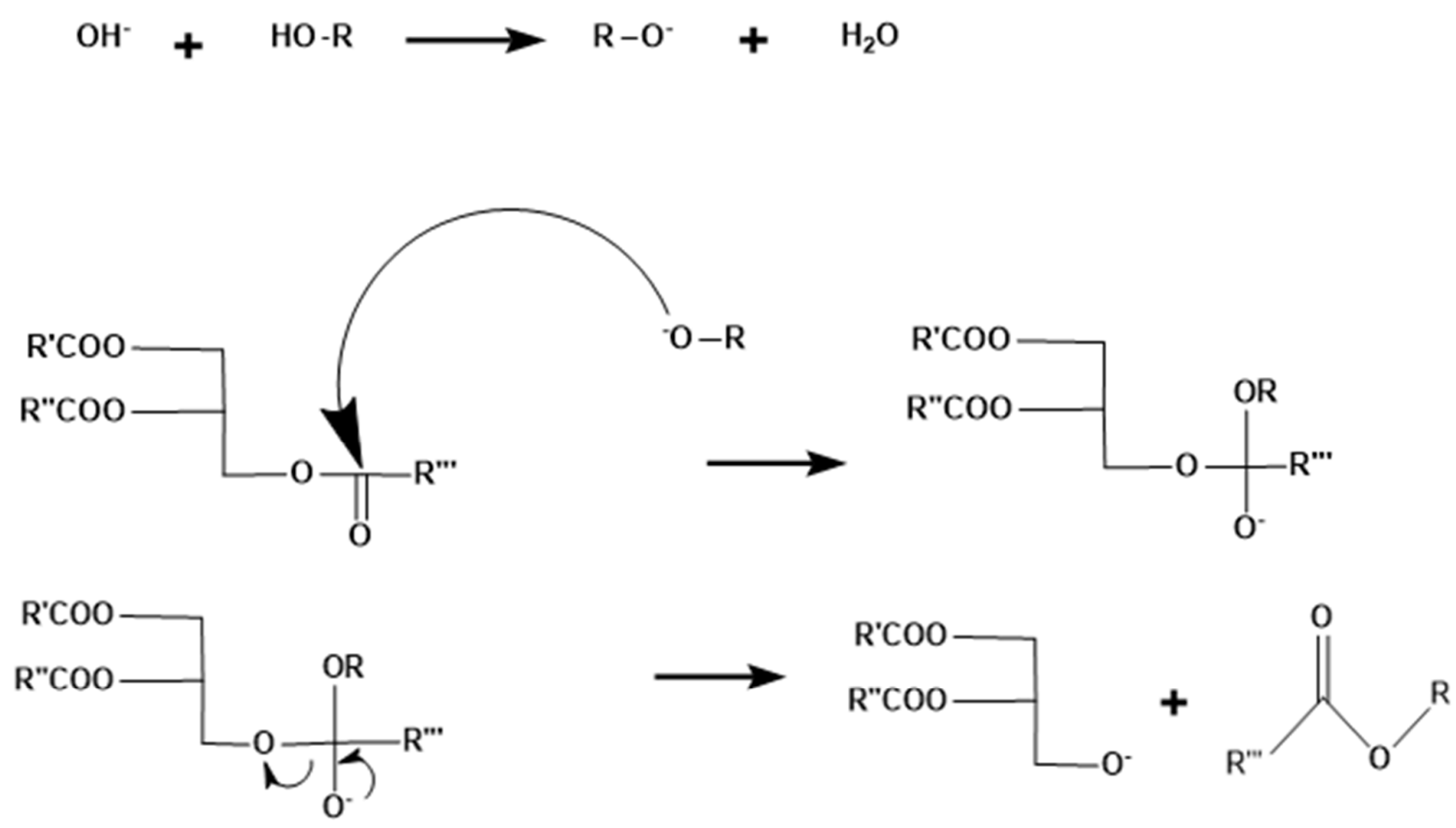

Figure 3. Base-catalyzed mechanism of homogeneous base catalyst.

\subsection{Mechanism of Homogeneous Acid-Catalyzed Reaction}

First of all, the carbonyl group of esters is protonated and forms a cation with an enhanced electrophile carbon which, on the attack of alcohol (nucleophile), yields tetrahedral intermediate. Then, the tetrahedral intermediate eliminates the glycerol to regain the catalyst and produce the new ester. The mechanism can be extended to diglycerides and triglycerides. The carbocation reacts with the water content of the reaction mixture and forms carboxylic acids, which minimize the yield of the desired product (alkyl esters). However, to avoid the competitive production of carboxylic acids, the transesterification reaction catalyzed by acid should proceed in the absence of water content (Figure 4).

\subsection{Merits and Demerits}

Nowadays, biodiesel is generally produced via the homogeneous base-catalyzed transesterification, as mild reaction conditions are required (low pressure and reaction temperature). The catalysts used in this process is widely available and the rate of homogeneous base-catalyzed transesterification is 4000 times greater than that of the acid-catalyzed process. However, this process is very sensitive to the FFA content of feedstock. For the base-catalyzed transesterification process, it is recommended that the FFA content in raw vegetable should be less than $1 \mathrm{wt}$. \% [56]. When the raw oil contains a large amount of FFAs, neutralization or saponification will occur. The saponification reaction is definitely unwelcome since it inactivates the catalyst and prevents the transesterification process, thus the yield of biodiesel is reduced [57]. The other drawbacks of using base catalysts are that the catalyst cannot be recovered after the process, and they need a high-quality raw material to avoid unwanted side reactions [3]. Using these catalysts also increase the biodiesel production cost since further purification and conditioning of the desired product are required [58]. Furthermore the crucial disadvantage of homogeneous catalysts $(\mathrm{KOH}$ and $\mathrm{NaOH})$ for biodiesel production is that they have a capability to absorb moisture from ambient air, and hence, are environmentally unsafe compared to the heterogeneous 
catalysts [59]. The acid-catalyzed transesterification is more advantageous than the basecatalyzed reaction when using the raw materials with a large amount of FFA. Indeed, acid catalysts have the capability to catalyze both transesterification and esterification simultaneously. So, the main advantage of using acid catalysts is that the low-quality feedstock (high concentrations of FFA) can directly produce FAME.<smiles></smiles><smiles>[R]C(=O)OCC(CO)OC([R])=CC=C</smiles>

Diglyceride<smiles>[R]C(=O)OCC(CO)OC([R])(O)[GeH](C)C</smiles>

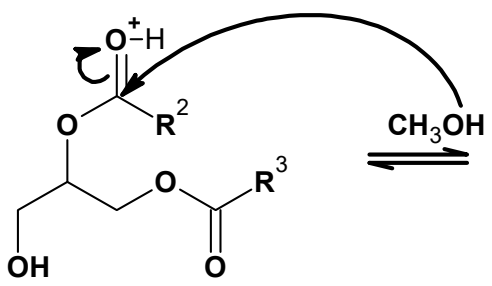<smiles>[R]C(=O)OCC(CO)OC([R])(O)[OH+]C</smiles><smiles>[R]C(=O)OCC(O)CO[Na]</smiles>

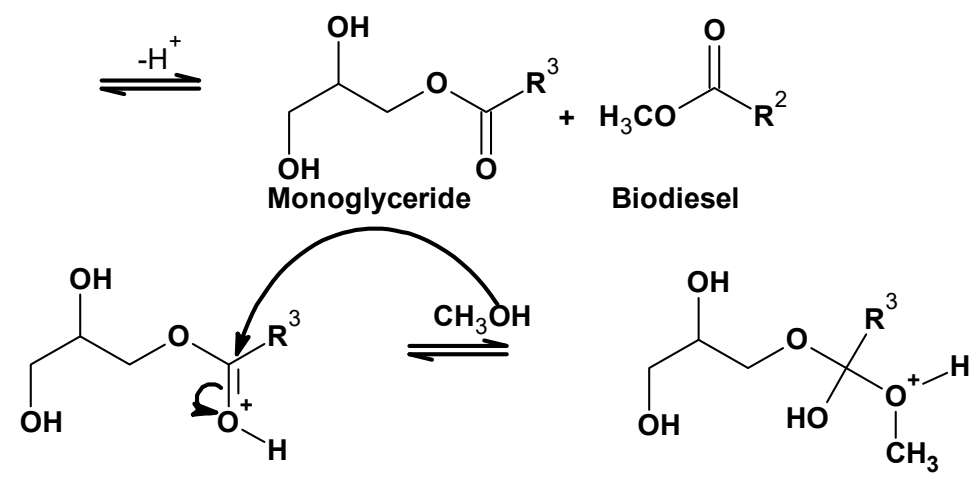
Monoglyceride<smiles>[R]C(O)(OCC(O)CO)C(C)(O)OC</smiles><smiles>[R]C(=O)OC</smiles>

Glycerol

Biodiesel

Figure 4. Acid-catalyzed mechanism of homogeneous acid catalyst. 


\section{Heterogeneous Catalysts}

Although biodiesel production from homogeneously catalyzed processes is comparatively fast and shows high conversion, these processes are still costly compared to the production of petro-diesel. In recent years, a new approach of using heterogeneous catalysts to produce biodiesel has attracted considerable attention. For the transesterification processes, a number of heterogeneous (solid) catalysts have been tested at the laboratory scale [60]. Biodiesel production using heterogeneous catalysts, instead of homogeneous catalysts, could possibly lead to cheaper production costs as it enables the reuse of catalysts $[3,61]$.

\subsection{Classification of Heterogeneous Catalysts}

Heterogeneous catalysts can be categorized into heterogeneous base catalysts and heterogeneous acid catalysts.

\subsubsection{Heterogeneous Base Catalysts}

Base or alkaline catalysts were not employed in the early period of biodiesel developmentas atmospheric components such as $\mathrm{H}_{2} \mathrm{O}, \mathrm{CO}_{2}$ and $\mathrm{O}_{2}$ could easily cover the basic sites, which generated hydroxide, carbonate, and peroxide, respectively, and weakened the function of basic sites. The general mechanism of heterogeneous base catalysts is shown in Figure 5. The most commonly studied solid bases used in the FAME production are carbonates of alkaline earth metals $\left(\mathrm{CaCO}_{3}\right)$, carbonates of alkali metals $\left(\mathrm{Na}_{2} \mathrm{CO}_{3}\right.$ and $\left.\mathrm{K}_{2} \mathrm{CO}_{3}\right)$, oxides of alkaline earth metals $(\mathrm{MgO}, \mathrm{CaO}, \mathrm{BaO}$ and $\mathrm{SrO})$ and other oxides, such as zinc oxide (Figure 6) [62,63].

\section{Single-Component Metal Oxides}

Single-component metal oxides include oxides of alkali metals, alkaline earth metals, oxides of rare earth oxides, $\mathrm{ZrO}_{2}, \mathrm{ThO}_{2}, \mathrm{TiO}_{2}$, and $\mathrm{ZnO}$, etc. [64-66]. Single-metal oxides catalysis is focused on during early studies of the heterogeneous catalyzed transesterification process. The transesterification process using single metal oxides is directly dependent on the oxide basicity [67].

\section{Alkaline Earth Metal Oxides}

Alkaline earth metals oxides such as $\mathrm{Mg}, \mathrm{Ba}, \mathrm{Sr}, \mathrm{Ca}$ and $\mathrm{Be}$, have been used for the production of biodiesel via the transesterification process [68].

\section{Calcium and Magnesium Oxides}

Among alkaline earth metals oxides, calcium oxide $(\mathrm{CaO})$ is one of the most promising solid base catalysts used in the transesterification process $[69,70]$, since it is found abundantly in nature, is cheap, and derives from some renewable sources. In general, $\mathrm{CaO}$ is produced from calcium carbonate $\left(\mathrm{CaCO}_{3}\right)$. In addition to these economic advantages, the catalytic activity of the $\mathrm{CaO}$ catalyst for FAME production is also comparable to a number of homogeneous catalysts. The natural calcium (Ca) sources from waste are found in crab shells, eggshells, and animal bones [71]. It was observed that the FAME yield was $93 \%$, using $\mathrm{CaO}$ which was earlier obtained from limestone $\left(\mathrm{CaCO}_{3}\right)$ calcinations, under optimal conditions [72]. Moreover, it was found that the FAME yield was $88.81 \%$ for the transesterification of ground nut using a $\mathrm{CaO}$ catalyst [73]. However, only a $20 \%$ FAME yield was reported for the transesterification of soybean oil at $100{ }^{\circ} \mathrm{C}$ using a $\mathrm{CaO}$ catalyst [41]. The transesterification process in the presence of $\mathrm{CaO}$ occurs in following steps. The proton $\left(\mathrm{H}^{+}\right)$is extracted from $\mathrm{CH}_{3} \mathrm{OH}$ at the basic site of $\mathrm{CaO}$, to form $\mathrm{CH}_{3} \mathrm{O}^{-}$. Then, in a triglyceride compound, the carbon atom of the carbonyl functional group is attacked by $\mathrm{CH}_{3} \mathrm{O}^{-}$to produce an alkoxy carbonyl compound, which rearranges itself to form FAME (the desired product) and diglyceride anion. Then, diglyceride anion attacks the calcium hydroxide cation to form diglyceride and $\mathrm{CaO}$. Hence, the catalyst $(\mathrm{CaO})$ is obtained once again after this process (Figure 7). 


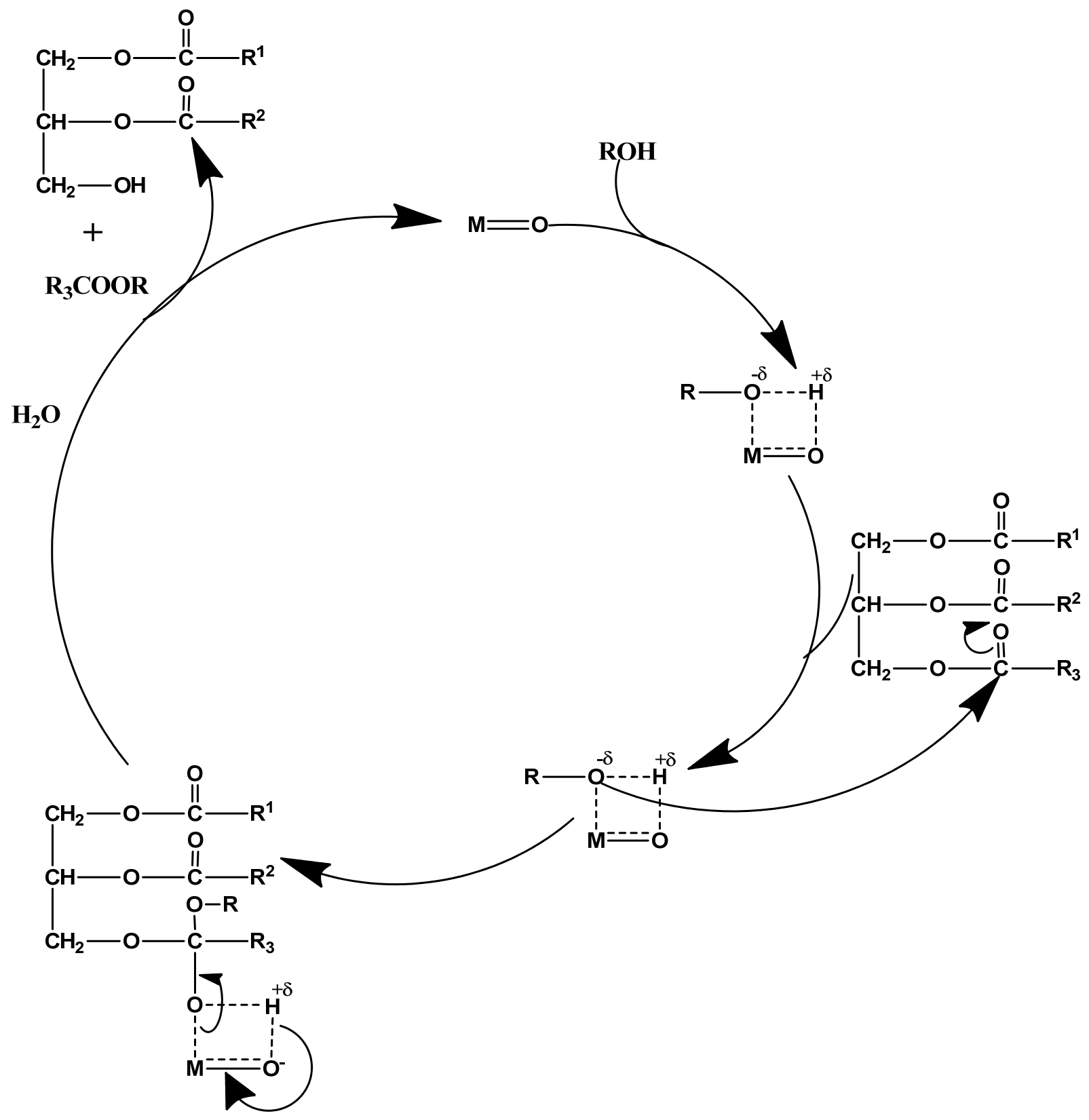

Figure 5. Chemical mechanism of a heterogeneous base catalyst.

Among the alkaline earth metals, magnesium oxide $(\mathrm{MgO})$ and $\mathrm{CaO}$ are widely used oxides and are abundant in nature. Calcined dolomite $\left(\mathrm{CaCO}_{3}+\mathrm{MgCO}_{3}\right)$ is used to prepare $\mathrm{MgO}$ and $\mathrm{CaO}$ catalysts for palm kernel oil transesterification. FAME yield was observed at 98\% under optimal conditions: a $6 \mathrm{wt}$ \% amount of catalyst, 30:1 methanol to oil molar ratio, $3 \mathrm{~h}$ of reaction time, and $60{ }^{\circ} \mathrm{C}$ of temperature. The used catalyst was successfully utilized for the production of FAME with a yield of more than $90 \%$ for seven successive reactions. Jatropha curcas oil transesterification by $\mathrm{CaO}$ yielded FAME of more than 95\%, under the optimum conditions: catalyst amount of $1.5 \mathrm{wt}$. \% of oil, $70{ }^{\circ} \mathrm{C}$ temperature, methanol to oil molar ratio 12:1, and $3.5 \mathrm{~h}$ of reaction time [74]. The solid catalyst activity is dependent on the active sites present on the surface of $\mathrm{MgO}$ or calcium oxide $(\mathrm{CaO})$. The activity of these catalysts decreases with time because their surface is poisoned by the absorption of water and carbon dioxide present in the air, forming hydroxides and carbonates, respectively. However, by the catalyst's calcination (removing $\mathrm{CO}_{2}$ and $\mathrm{H}_{2} \mathrm{O}$ at a high temperature) the catalytic activity of these catalysts can be recovered. $\mathrm{CaO}$ was 
exposed to the air for 4 months ( 120 days), at temperatures of $200{ }^{\circ} \mathrm{C}, 500{ }^{\circ} \mathrm{C}$ and $700{ }^{\circ} \mathrm{C}$, respectively. At $200{ }^{\circ} \mathrm{C}$, the $\mathrm{CaO}$ catalyst provided a very low activity. At $500{ }^{\circ} \mathrm{C}$, the catalytic activity of the catalyst improved due to the $\mathrm{Ca}(\mathrm{OH})_{2}$ dehydration present in $\mathrm{CaO}$. At $700{ }^{\circ} \mathrm{C}$, the best catalytic activation of the catalyst could be achieved due to the conversion of the calcium carbonate $\left(\mathrm{CaCO}_{3}\right)$ to $\mathrm{CaO}$ [75].

\section{Heterogeneous base catalysts}

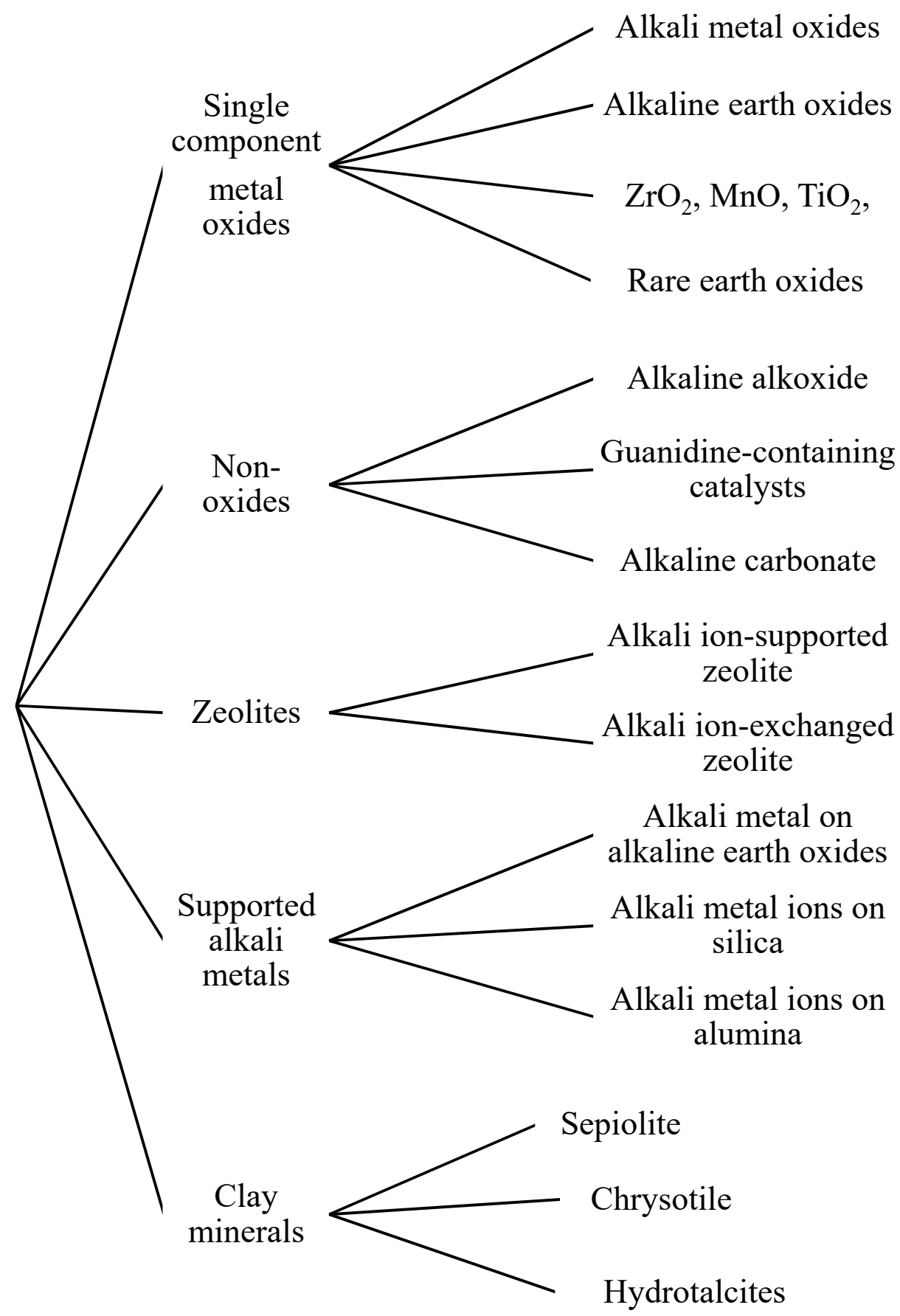

Figure 6. Classification of heterogeneous base catalysts. 

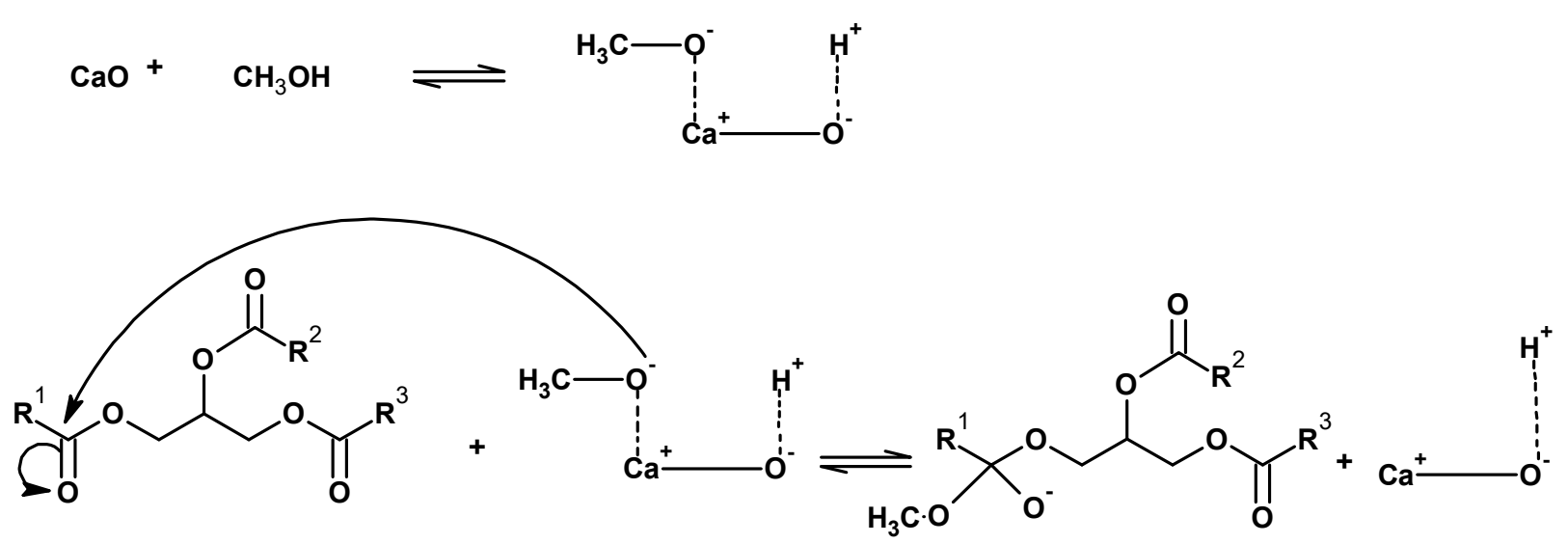<smiles>[R]C(=O)OCC(COC1([R])CCCO1)OC([R])=O</smiles><smiles>[R]C(=O)OCC(C[O])OC([R])=O</smiles>

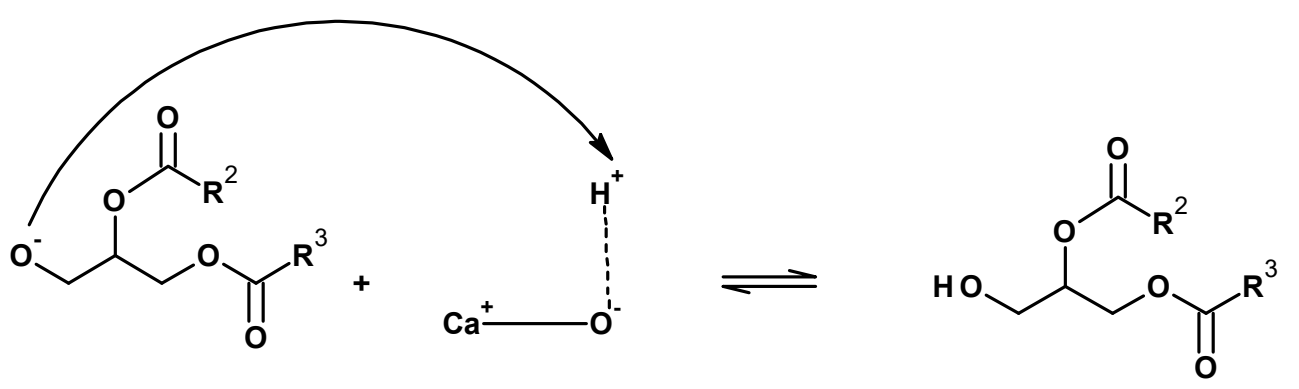

Figure 7. Chemical mechanism of calcium oxide $(\mathrm{CaO})$.

The catalytic activity of $\mathrm{MgO}$ is very low compared to $\mathrm{CaO}$. Studies reveal that the mixed magnesium-alumina $(\mathrm{Mg}-\mathrm{Al})$ oxide calcines at very high temperature, uses hydrotalcites $\left(\mathrm{Mg}_{6} \mathrm{Al}_{2}(\mathrm{OH})_{16} \mathrm{CO}_{3} \cdot 4 \mathrm{H}_{2} \mathrm{O}\right)$ as precursors, and has good catalytic activity. With the use of this catalyst, the FAME yield was found to be $>90 \%$ in spite of using a high reaction temperature [76]. In another study, the same results were also obtained by using the oxides of magnesium-alumina as a catalyst [57].

\section{$\mathrm{ZrO}_{2}, \mathrm{MnO}, \mathrm{TiO}_{2}$}

The rates of transesterification of solid bases are typically higher than that of solid acids. Hence, in biodiesel production, the oxides of transition metals of different Lewis base characters have been used [77]. $\mathrm{TiO}_{2}$ and $\mathrm{MnO}$ are mild bases which have good catalytic activity for FAME production. These heterogeneous base catalysts can be applied for the transesterification of TAG using low-quality feedstocks which contain high FFAs contents $(>15 \%)$. Zirconium $(\mathrm{Zr})$ has also been used as a solid basic catalyst for FAME production. Mixed oxides of $\mathrm{CaO}$ and zirconium dioxide $\left(\mathrm{ZrO}_{2}\right)$ show increased stability and surface area. However, the catalytic activity of the transesterification process is mainly dependent upon $\mathrm{Ca}$ content. The catalytic activity increased with higher $\mathrm{CaO}$ loadings and decreased with lower $\mathrm{CaO}$ loadings. Zirconia acts as a supportive site for a number of sodium-containing bases, such as $\mathrm{NaH}_{2} \mathrm{PO}_{4}$ (sodium dihydrogen phosphate), $\mathrm{NaOH}$, $\mathrm{KNaC}_{4} \mathrm{H}_{4} \mathrm{O}_{6} \cdot 4 \mathrm{H}_{2} \mathrm{O}$ (potassium sodium tartrate), and $\mathrm{C}_{4} \mathrm{H}_{5} \mathrm{O}_{6} \mathrm{Na}$ (monosodium tartrate). These sodium-containing bases were doped on $\mathrm{ZrO}_{2}$ to produced catalysts with different basic strengths. The catalytic activity of catalysts depended upon their basicity; at higher $\mathrm{Na}: \mathrm{Zr}$ ratios the catalytic activity increases. The potassium sodium tartrate-doped zirconia show the strongest basicity and hence, the highest catalytic activity [18]. 
The zirconium oxide $\left(\mathrm{ZrO}_{2}\right)$ catalyst is also frequently used along with alumina to form $\mathrm{ZrO}_{2}-\mathrm{Al}_{2} \mathrm{O}_{3}$, or by infusing with an acidic solution, such as $\mathrm{H}_{2} \mathrm{SO}_{4}$, to form sulfated zirconia $\left(\mathrm{SO}_{4}{ }^{2-}-\mathrm{ZrO}_{2}\right)$. It was observed that this catalyst could combine with tungsten and alumina oxide $\left(\mathrm{ZrO}_{2}-\mathrm{Al}_{2} \mathrm{O}_{3}-\mathrm{WO}_{3}\right)$ to improve the mechanical strength of the catalyst [78].

\section{Mixed Metal Oxides}

Mixed oxides of $\mathrm{Al}_{2} \mathrm{O}_{3}-\mathrm{SnO}$ and $\mathrm{Al}_{2} \mathrm{O}_{3}-\mathrm{ZnO}$ were prepared and the effectiveness of these catalysts was observed [79]. The FAME yield was about $80 \%$ from soybean oil when using these catalysts. The biodiesel yield dramatically decreased to $28.3 \%$ when the ethyl alcohol was used instead of methyl alcohol [80]. The catalysts of Mg-La oxides were also examined for the transesterification process. The basic character of the catalysts of $\mathrm{Mg}-\mathrm{La}$ oxides increased with the increase in the magnesium content in mixed oxides. The conversion of sunflower oil reached $100 \%$ using Mg-La oxide. The performance of Mg-La oxides catalyst was compared with the performance of $\mathrm{SrO}, \mathrm{CaO}, \mathrm{Li}-\mathrm{Al}$ and $\mathrm{Mg}-\mathrm{Al}$ oxides, and it was found that $\mathrm{Mg}$-La oxides performed well in producing FAME, when compared to other catalysts. Moreover, these catalysts had the capability to tolerate FFAs and water content in reaction media during FAME production [81]. In terms of Hammett basicity $(\mathrm{H})$, the catalysts of the $\mathrm{Ca}$ series, such as $\mathrm{Ca}_{2} \mathrm{Fe}_{2} \mathrm{O}_{5}, \mathrm{CaMnO}_{3}, \mathrm{CaCeO}_{3}$, and $\mathrm{CaZrO}_{3}$ exhibited high base strengths, while the catalysts of the $\mathrm{La}, \mathrm{Mg}$ and $\mathrm{Ba}$ series exhibited weak base strengths. These results were related to the transesterification process, in which catalysts of the $\mathrm{Ca}$ series exhibited good catalytic activities. Especially, $\mathrm{CaO}-\mathrm{CeO}_{2}$ and $\mathrm{CaZrO}_{3}$ catalysts showed 80\% FAME yields. However, in some applications, suspensions of some $\mathrm{CaO}$ catalysts were also formed, leading to difficulties in separating the catalysts from the products. This problem was resolved by the impregnation of $\mathrm{CaO}$ catalysts in metal oxide carriers [82]. In a previous study, neutral oxide $\left(\mathrm{SiO}_{2}\right)$, basic oxide $(\mathrm{MgO})$, zeolite $(\mathrm{HY})$, and acidic oxide $\left(\mathrm{Al}_{2} \mathrm{O}_{3}\right)$ were used as supports, and with $\mathrm{CaO} / \mathrm{MgO}$ the best result was achieved; in this case the yield of biodiesel from the rapeseed oil was $92 \%$ [83].

\section{Zeolites}

Zeolites are among the group of solid acids which are extensively used as catalysts in several industrial processes $[84,85]$. To produce biodiesel, zeolites play an important role as a catalyst. Two methodologies are generally carried out to control zeolite basicity: ion exchange with ions of alkali metal and the impregnation of basic constituents on the internal surfaces of zeolite pores. From the experiments, it has been concluded that the former method generates weak basic sites when compared to the latter method. For biodiesel production, titanosilicates, mesoporous zeolites, and zeolite- $X$ are the most important zeolites used as catalysts. In general, zeolite $X$ is considered as the most basic of zeolites and its basicity increases markedly when the $\mathrm{Na}-\mathrm{X}$ ion exchange with the larger monovalent cations, such as potassium $(\mathrm{K})$, occurs. It was observed that the ion exchange with cesium (Cs) was less effective than that with $\mathrm{K}$, because $\mathrm{Cs}^{+}$has a larger size which limits the capacity of exchange, compared to that of the smaller potassium ion $\mathrm{K}^{+}$. The size of an ion affects its basicity which is associated with oxygen framework [86]. Zeolites of the Engelhard titanosilicate structure (ETS) series have received attention from researchers because of their high ion exchange capacities, strong basic characters, and distinctively large pore structures. The idea of using titanosilicate as a catalyst for FAME production derives from the requirement for titanium species to be fixed into the structure of a solid lattice. For the fixation of titanium, different approaches are used, such as titanium (Ti) supported on $\mathrm{SiO}_{2}$ as an alkoxide, titanium-grafted $\mathrm{SiO}_{2}$, and titanium anchoring on polymers. ETS-10 is a titanosilicate which has a microporous structure consisting of tetrahedral silicon $\left(\mathrm{SiO}_{4}{ }^{4-}\right)$ and octahedral titanium $\left(\mathrm{TiO}_{6}{ }^{8-}\right)$. ETS-10 is about four times more basic than that of Na-X. Furthermore, it is observed that the ETS-10 catalyst provides better triglyceride conversions, compared to $\mathrm{Na}-\mathrm{X}$ (Figure 8) [86]. It is reported by some researchers that $\mathrm{La}_{2} \mathrm{O}_{3} / \mathrm{NaY}$ spherical particles $(3-5 \mathrm{~mm}$ ) provide an $84.6 \%$ biodiesel yield under optimal 
conditions: 10 wt. $\%$ of catalyst concentration, $15: 1$ of ethanol-to-oil molar ratio, a $70{ }^{\circ} \mathrm{C}$ reaction temperature and $50 \mathrm{~min}$ of reaction time [15].

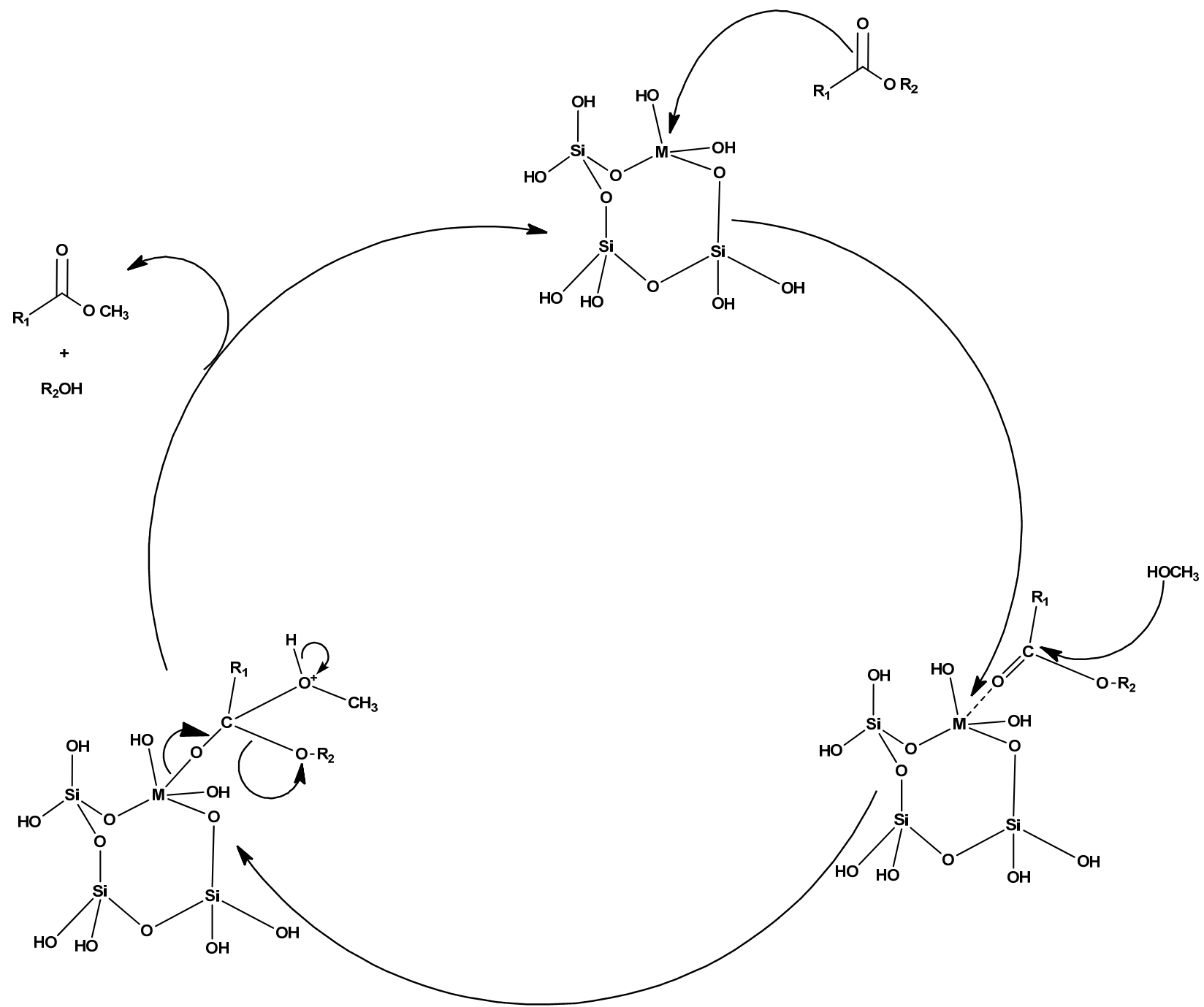

Figure 8. Chemical mechanism of a heterogeneous acid catalyst.

Supported Alkali Metal/Metal Ion Catalysts

For FAME production alkali metals or alkaline earth metals are thought of as supported catalysts' active species. $\mathrm{K}, \mathrm{Na}, \mathrm{Li}, \mathrm{Mg}$ and $\mathrm{Ba}$ are commonly used in metallic form or as several ionic forms: carbonate, halide, nitrate and hydroxide [87-90]. In terms of catalytic activity and basicity, supported halide catalysts exhibit the best results. For instance, $\mathrm{KI} / \mathrm{Al}_{2} \mathrm{O}_{3}$ and $\mathrm{KF} / \mathrm{Al}_{2} \mathrm{O}_{3}$ catalysts mostly exhibited higher catalytic activities for the transesterification process than $\mathrm{KNO}_{3} / \mathrm{Al}_{2} \mathrm{O}_{3}, \mathrm{KOH} / \mathrm{Al}_{2} \mathrm{O}_{3}$, and $\mathrm{K}_{2} \mathrm{CO}_{3} / \mathrm{Al}_{2} \mathrm{O}_{3}$. The catalytic activities of carbonates, hydroxides and nitrates, which supported $\mathrm{Al}_{2} \mathrm{O}_{3}$ catalysts, are different depending on the impregnated $\mathrm{K}$ amount. The catalytic activity and basicity of $\mathrm{KF} / \mathrm{Al}_{2} \mathrm{O}_{3}$ is weakly dependent on the amount of impregnated $\mathrm{K}$, compared to that of $\mathrm{KNO}_{3} / \mathrm{Al}_{2} \mathrm{O}_{3}$ and $\mathrm{K}_{2} \mathrm{CO}_{3} / \mathrm{Al}_{2} \mathrm{O}_{3}$.

Organic Solid Bases Guanidine

Guanidine $\left[\mathrm{C}(\mathrm{NH})\left(\mathrm{NH}_{2}\right)_{2}\right]$ is a crystalline compound with a strong basic character. Alkylation of this molecule produces alkyl guanidine which is a strong organic base. Triazobicyclodecene (TBD) is the most well-known commercial alkyl guanidine, and is efficiently used to catalyze the transesterification process [76]. The transesterification of rapeseed oil 
in the presence of the TBD catalyst yielded 90\% FAME. The most important advantage of alkyl guanidine is that it tolerates the use of crude acidic oil and simplifies glycerol-FAME separation, as the guanidine-FFA complex is easily solubilized in the reaction mixture and does not produce emulsions or soap. Guanidine is heterogenized by bonding the TBD on the substituted polystyrene (PS). The catalytic activity is observed to be somewhat lower than the homogeneous system because of the polymer support hydrophobicity and decreased symmetry of alkyl guanidinium ions, yet the actual issue was guanidine leaching. The next strategy of heterogenizing the alkyl guanidine is the encapsulation of alkyl guanidine in the super cages of zeolite $\mathrm{Y}$ and the trap in $\mathrm{SiO}_{2}$. Heterogeneous guanidine catalysts require further research about heterogenization strategies.

\section{Hydrotalcites}

Hydrotalcites are also used as heterogeneous base catalysts. These have a high activity, as well as a durability in the presence of water content, which is why they are popular with researchers [91]. The catalytic activity of $\mathrm{Mg}-\mathrm{Al}$ hydrotalcites observed for the transesterification of high- and poor-quality oil feeds, such as animal fat feed (possessing $45 \mathrm{wt}$. \% water) and acidic cottonseed oil (having $9.5 \mathrm{wt}$. \% FFAs), provides a 99\% conversion of feedstock within $3 \mathrm{~h}$. Moreover, it is necessary to note that the use of hydrotalcites as catalysts for the transesterification process are suspected due to the use of alkali (Na or K) and carbonate/hydroxide solutions for the precipitation of the hydrotalcites phase, because it is very difficult to remove alkali residues from the resulting hydrotalcites. This issue can be overcome by adopting another approach for the precipitation of hydrotalcites which is alkali-free; usually $\left(\mathrm{NH}_{4}\right)_{2} \mathrm{CO}_{3}$ and $\mathrm{NH}_{3}$ are used to precipitate the hydrotalcites phase. Furthermore, hydrotalcites prepared by conventional methods have a microporous structure and are unable to transesterify bulky TAG groups $\left(\mathrm{C}_{16}-\mathrm{C}_{18}\right)$, which are the main constituents of raw materials (bio-oils). The solution to this problem is to utilize catalysts which have a bimodal pore distribution, and micropores which provide base sites and a high surface density, while a corresponding macro or mesopores network is responsible for the rapid transport of TAGs to these active sites from bulk reaction media and the removal of products (glycerol and fatty acid methyl ester) from the catalyst [18].

\subsubsection{Heterogeneous Acid Catalysts}

Heterogeneous acid catalysts have a high potential to replace liquid acid catalysts in order to eliminate corrosion problems, as well as the environmental hazards caused by liquid acid catalysts [92]. The general mechanism of the heterogeneous acid catalyst is depicted in Figure 8. In the esterification process, the use of homogeneous acid catalysts requires both neutralization and separation steps. Therefore, it would be need to be perform the esterification pretreatment step with a solid acidic catalyst, considerably simplifying the separation and reducing the net number of processing steps [3]. Even though the rate of the heterogeneous acid-catalyzed transesterification process is low, this method has been used for industrial processes because heterogeneous catalysts have the ability to catalyze both the transesterification and esterification processes at the same time. This catalyst is less corrosive, and toxic compared to the homogeneous acid catalyst, more insensitive to FFAs contents, and can easily seperate, regenerate and recycle from the reaction mixture. Furthermore, this process also excludes the biodiesel washing process. However, the solid acid-catalyzed transesterification process also has disadvantages, such as a slow rate of reaction and unwanted side reactions. The transesterification of soybean oil has been studied using different solid super acids as catalysts, such as sulfated zirconia alumina (SZA), tungstated zirconia alumina (WZA), and sulfated tin oxide (STO), of which the WZA catalyst is the most effective [93]. The classification of heterogeneous acid catalysts is shown in Figure 9. 


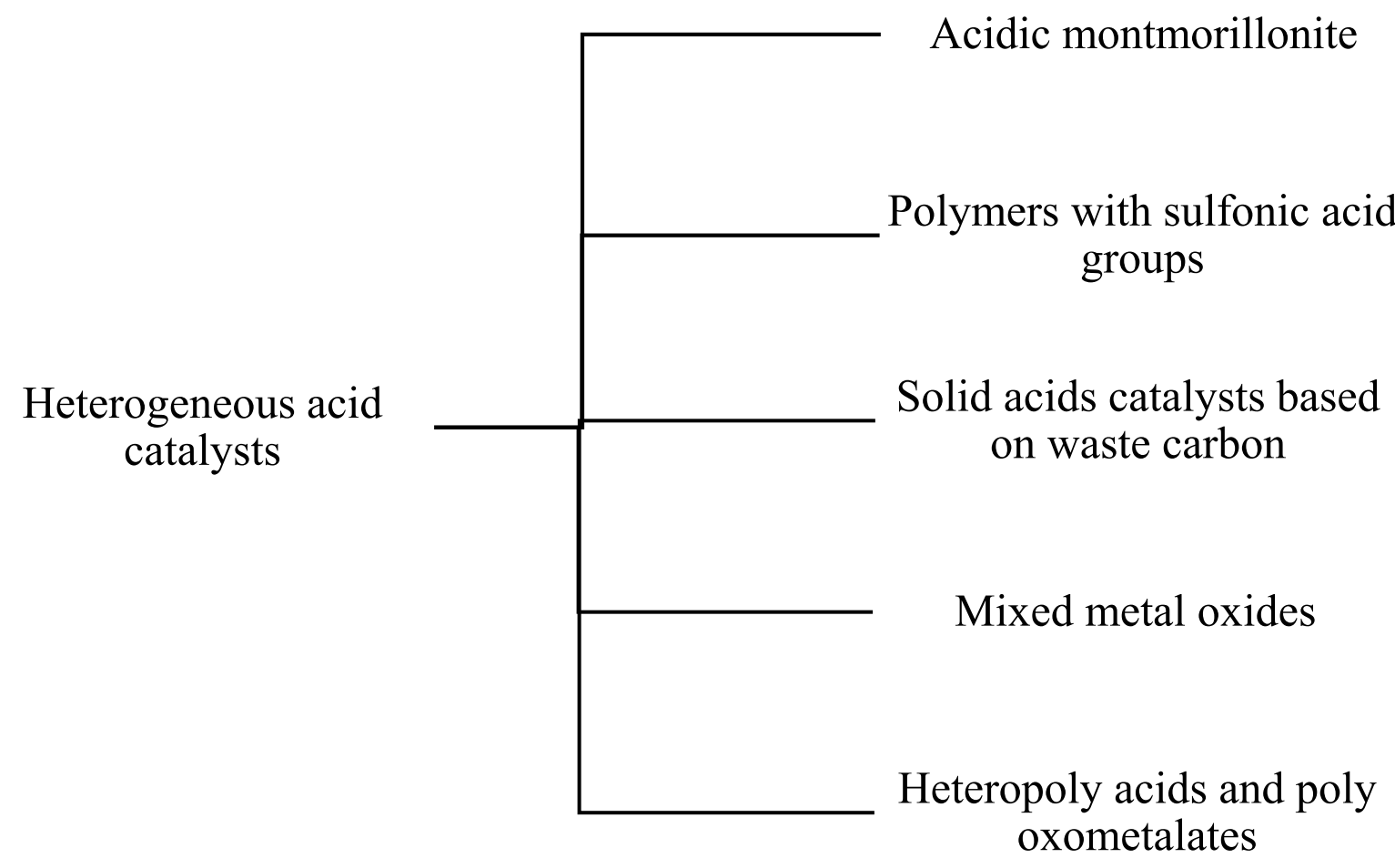

Figure 9. Classification of heterogeneous acid catalysts.

Acidic Montmorillonite

Acidic montmorillonite clays are pillared, amorphous or naturally occurring alumino silicates layers [94]. These catalysts are used in several industrial processes. These clay catalysts are considered a good species for the transesterification process, particularly with suitable advances. The polymerization between the clays generates two dimensional sheets which improve the activity of the clay catalysts. During this process, octahedral sheets $\left(\mathrm{MO}_{6}\right.$, where $\mathrm{M}=\mathrm{Fe}^{3+}, \mathrm{Mg}^{2+}, \mathrm{Al}^{3+}, \mathrm{Fe}^{2+}, \mathrm{Ti}^{4+}, \mathrm{Sn}^{4+}$ and $\left.\mathrm{Sc}^{3+}\right)$ are sandwiched in tetrahedral silicate sheets $\left(\mathrm{SiO}_{4}\right)$. This is why, when the dissociation of water molecules occurs from the hydration sphere, it generates Brønsted acids $\left(\mathrm{H}^{+}\right)$. Consequently, depending upon the nature of the reacting species, clay catalysts with multivalent metal cations are replaced within its structure, and demonstrate both Lewis and Brønsted acidity. Catalytic activities and the Lewis/Brønsted acidity of clay catalysts are mainly dependent on the electronegativity of interlamellar replaceable cations which are attached to alumino silicate sheets (negatively charged). Moreover, the octahedral sheets $\left(\mathrm{MO}_{6}\right)$ contain oxygen atoms which are associated with multivalent metal cations that have a lower valency. The electronic configuration difference provides a net negative charge to the overall sheets while this negative charge compensates for the hydrated cations present in the interlamellar spaces. This provides the clay with a swelling ability when dipped in an aqueous medium. When the swelling effect discloses intercalated cations, catalytic activities increase.

\section{Mixed Metal Oxides}

The Lewis acids (cations) and Brønsted acids (anions) of metal oxides give catalytic sites required for transesterification process. The splitting of the $\mathrm{O}-\mathrm{H}$ bond generates hydrogen cations and methoxide ions that facilitate the transesterification reaction. So, numerous transition metal oxides like zinc oxides, titanium oxides and zirconium oxides are receiving attention from researchers [12]. Among these heterogeneous acid catalysts, tungstated and sulfated zirconia are prominent catalysts for the transesterification process. Zirconia catalysts are well-known at an industrial scale because of their advantages; they possess strong acidic sites and are thermally stable. Diffusional limitations are minimized by the large pores of zirconium oxides. Side reactions such as dehydration, as well as 
etherification, do not occur when zirconia is used as catalyst. The efficiency of the zirconia catalyst is dependent upon the preparation method and other synthetic parameters $(\mathrm{pH}$ calcination, post thermal treatments and the precursor type), although the leaching effect on the sulfated zirconia catalyst is minimal during the process of esterification. Three different mixed metal oxide catalysts, such as alumina mixed with titanium oxide $\left(\mathrm{TiO}_{\mathrm{x}}\right)_{\mathrm{y}}\left(\mathrm{Al}_{2} \mathrm{O}_{5}\right)_{1-\mathrm{y}}$, zirconium oxide $\left(\mathrm{ZrO}_{\mathrm{x}}\right)_{\mathrm{y}}\left(\mathrm{A1}_{2} \mathrm{O}_{5}\right)_{1-\mathrm{y}}$, and antimony oxide $\left(\mathrm{SbO}_{\mathrm{x}}\right)_{\mathrm{y}}\left(\mathrm{A1}_{2} \mathrm{O}_{5}\right)_{1-\mathrm{y}}$ are used for the transesterification of vegetable oils in order to compare their catalytic activities and auditability for efficient FAME production; it was noted that $95 \%, 99.3 \%$ and $96 \%$ of the oil is converted into FAMEs, respectively. The catalytic activities of alkaline earth metals (calcium, barium, or magnesium) supported on mesoporous silica are also investigated by some researchers. It is concluded that the silica sites are responsible for Lewis acidity, while the hydroxyl group present on the surfaces of the mixed catalysts are responsible for Brønsted acidity. The composite matrix eased the conversion of feedstock with high FFAs content to FAME. For example, a positive charge difference is generated at calcium oxide octahedral sites when silicon atoms replace calcium atoms. Hence, this causes an increase in the efficiency of silicate mixed oxide catalysts, more so than pure calcium oxide catalysts. The vanadium phosphate catalyst is another promising solid acid catalyst. This catalyst yields $80 \%$ FAME under mild conditions of the transesterification reaction. However, any increase in temperature to obtain higher yields has an adverse effect. At high temperatures, the vanadium reduces from $\mathrm{V}^{5+}$ to $\mathrm{V}^{3+}$ which causes the deactivation of the catalyst. Furthermore, to attain a higher FAME yield, a longer reaction time is required. Hence, more research is required to make these catalysts affordable and stable [39].

\section{Polymer Catalysts with Sulfonic Acid Groups}

This group of catalysts is characterized by sulfonated crosslinked polystyrene and is comparable to toluene sulfonic acid in acidic activity. Although the cost of these catalysts is higher than the cost of mineral acids, these catalysts are still used due to key advantages, such as less corrosion and ease of product separation. The most general catalysts among the ion-exchange family are Amberlyst and nonporous Nafion resins. The chain of polymers within these catalysts controls their hydrophobicity. Fatty acid (FA) tails and alcohol strongly attract polymer backbones. Moreover, the strong sulfonic acid groups grafted on the chain of polymers promote larger acidic sites, compared to $\mathrm{OH}$ groups on zeolites or metal oxides. Interestingly, ion-exchange resins perform differently depending on the reacting media composition. The efficiency or activities of these catalysts depend on the differences in the swelling behavior of the resins in diverse reaction media. Conversely, resins that have an enhanced porosity due to a high divinyl benzene content, exhibited higher FAME yields. Usually, the ion-exchange resins, as organic solid acids, are poor in both thermostability and in activity. Accordingly, these catalysts are only applicable to reactants that have a low molecular weight, as well as low boiling point. The desulfonation of the resin occurs in the presence of excess water and metal ions at high temperatures, as, when the water molecules interact with sulfonic acid groups, they dissociate with the active sites. The catalyst that is deactivated by the excess water can be recovered by heating at $473 \mathrm{~K}$. Therefore, it can be deduced that more research is needed for the industrial production of FAME with the use of these catalysts [39].

\section{Heteropoly Acids and Polyoxometalates (Isopoly and Heteropoly Anions)}

A promising field for catalytic biodiesel production is the use of heteropoly acids (HPAs) and polyoxometalate compounds. The general structure of these acids consists of an $\mathrm{XO}_{4}$ (central tetrahedron) surrounded by an octahedral metal-oxygen. Keggin heteropoly anion is the first characterized heteropoly acid. It is the best catalyst among HPAs, represented as $\mathrm{XM}_{12} \mathrm{O}_{40}{ }^{\mathrm{x}-8}$ (where $\mathrm{X}$ symbolizes the central atom such as $\mathrm{P}^{5+}$ or $\mathrm{Si}^{4+}$

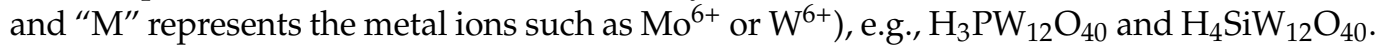
Other metal ions like $\mathrm{V}^{5+}, \mathrm{Zn}^{2+}$ and $\mathrm{Co}^{2+}$ can easily replace these ions during preparation. The flexibility of catalyst structure and its super acidic properties can be improved by 
the incorporation of polyoxometalate anions into the complex proton acids. The catalyst under this condition has mobile heteropoly anions and counter cations (e.g., $\mathrm{H}_{5} \mathrm{O}_{2}{ }^{+}, \mathrm{H}_{3} \mathrm{O}^{+}$, $\mathrm{H}^{+}$). This characteristic property provides the heteropoly acids (HPAs) with great proton mobility and a reacting medium called "pseudo liquid phase". This pseudo liquid phase enables almost all of the mobile protons to take part in catalysis. The pseudo liquid phase guarantees greater catalytic activities. There are some attributes of HPAs which reduce the costs, such as the absence of side reactions, fair thermal stability, and the capability of stabilizing organic intermediates within the pseudo liquid phase. However, the HPAs are not appropriate for FAME production in their native forms because they are highly soluble in polar media and have low numbers of available surface acidic sites. To attain a greater number of available acidic sites, researchers provide support to HPAs. Supported HPAs have advantages, such as more thermal stability, when compared to ion exchange resins, stronger acidity, and insolubility in polar media. The large surface area of supportive material enhances the stability of the catalysts [39]. It is reported by some researchers that $90 \%$ feedstock conversion into biodiesel occurs in the presence of the $\mathrm{H}_{3} \mathrm{PW}_{12} \mathrm{O}_{40}$ catalyst (supported on the magnetic iron oxide particles) at a temperature of 338K [95].

\section{Solid Acids Catalysts Derived from Waste Carbon}

The biomass of the solid acid catalyst by using the carbonized residue of non-edible seeds via sulfonation, is produced. Carbonaceous materials, which are obtained after sulfonation, show a promising catalytic activity in the transesterification process. When incompletely carbonized carbohydrates, such as cellulose, sugar, starch, sucrose, and glucose are sulfonated, rigid carbon material comprising of small polycyclic sheets of aromatic carbon is formed [96]. Sugar shows a higher catalytic activity for the esterification of oleic acid than any other heterogeneous acid catalysts. Experimental results revealed that the sugar catalyst, even after $>50$ cycles of successive reuse, provided a higher FAME yield than other heterogeneous acid catalysts. The catalytic activity temperature for the sugar catalyst is $>275{ }^{\circ} \mathrm{C}$. Carbon-based heterogeneous acid catalysts synthesized from biochar sulfonated material are also used for biodiesel production [19]. This catalyst is employed to biodiesel production from canola oil, which has large FFAs contents. This solid (heterogeneous) acid catalyst is comprised of a flexible framework of carbon with extremely dispersed polycyclic aromatic hydrocarbons with sulfonic acid groups. This catalyst processes high catalytic activity, as well as stability. The hydrophobic functional groups prevent the hydration of the ${ }^{-} \mathrm{OH}$ species while hydrophilic functional groups provide an improved accessibility of methyl alcohol to the FFAs, triglyceride, and to its large pores that provide more acid sites with reacting substances [97].

\subsection{Merits and Demerits}

Heterogeneous catalysts have the following advantages: no introduction of water, no neutralization step, and no formation of salt. Moreover, there is no production of waste material from low-value fatty acids. The methyl esters purity exceeds $99 \%$. Treatment of glycerol is much easier than that of the homogeneous catalyzed processes. Methanol is eliminated via vaporization and no chemicals are required. The glycerol produced is free from any salt, and clear and neutral, with purities above $98 \%$. Without further treatment, this valuable byproduct can be used in many chemical applications; the equipment and investment-related cost is also less than other catalysts. The only products of the heterogeneous catalyzed transesterification process are biodiesel and a high-purity glycerol that is free from any salt and water. With all these features, the heterogeneous catalyzed process can be thought of as a green process [98]. The main disadvantage is that the energyand utility-related cost is high. As the heterogeneously catalyzed transesterification required a higher pressure and temperature than that of the homogeneous one, high energy consumption is required and therefore, the energy-related costs of this process are high [99]. 


\subsection{Biocatalysts}

As there are various disadvantages associated with the use of acid and base catalysts for the FME production, biocatalysts are attracting the attention of modern researchers. Among biocatalyst, lipase is the most used catalyst. For the efficient FAME production at a large scale, two factors are important: lipase screening and bioprocess design using a number of feedstocks. Due to their easy availability and production, lipases have become potential biocatalysts for various industrial applications. However, there are a number of disadvantages associated with the use of native lipases and with the conventional purification methods from microbial cultures, such as low stability, and the low yield. In order to produce FAME from the transesterification process in the presence of lipases, molecular techniques for the recombinant production of heterologous lipases in a host have been developed successfully. The use of lipase technology for the FAME production at industrial level is in the early stages. Although, recently, researchers attempted to generate lipase variants. The structural insights into the stability of lipase, along with the primary screenings, have opened prospects for obtaining lipase variants with a high capability to tolerate industrially relevant conditions. The versatility of lipases is promising for the intensification of the process, where costly and time-consuming steps can most likely be avoided [100]. The use of the lipase enzyme for the FAME production was reported by Mittelbach, in 1990 [101]. The general advantages of the use of biocatalysts for the production of biodiesel are as follows: the versatile activity of the lipase enzyme for the efficient FAME production via transesterification; the use of relatively low pressures and temperatures, consequently reducing the consumption of energy [10]; and the easy recovery of glycerol and biodiesel [102]. The transesterification process catalyzed by lipases is likely to provide substantial benefits, mainly in the reaction engineering and intensification of the process for FSME production. With the use of cheap feedstocks like crude (non-degummed oils) and unrefined oils that have a relatively high amount of FFAs and other impurities, the cost of biodiesel production can be reduced. Yet, there are several factors that inhibit the use of biocatalysts for the production of biodiesel using crude oils, that have been reported [103]. For example, it was found that phospholipids interfere with the contact between the substrate and lipase. Recently, it has been found by some researchers [104] that, apart from plant oils, microbial oils also contain phospholipids (about $30 \%$ ). The preparation of biocatalysts was shown by Amoah et al. $[11,105]$ to be a simple technique to overcome the low yield of FAME even in the presence of the high content of phospholipid.

Furthermore, metagenomics (extracting all microbial genomic DNAs from certain environmental habitats) are likely to broaden the microbial resource utilization scope, consequently allowing for the efficient screening of lipase for FAME production [106]. The agro-industrial residues containing lipase enzymes, which are produced during the process of solid-state fermentation, can be used directly for the production of FAME in order to avoid the costly steps of the preparation of lipase [107].

\section{Future Prospects}

Biodiesel has great potential to play a vital role in achieving renewable fuel targets, although developments in the material design are advantageous to attain substantial improvements in FAME production from heterogeneous catalysts. Designer heterogeneous base and acid catalysts with pore networks and tailored surface properties are found to be good for process improvements more than existing homogeneous catalysts do. Heterogeneous catalysts have the capability for the simultaneous esterification of FFAs and the transesterification of triacylglycrides under normal conditions, presenting a most important task for catalytic scientists. We expect that, in the future, hierarchical heterogeneous acid catalysts may be active, first to hydrolyze and then to esterify the resulting FFAs to FAME. The synthesis of nanostructured catalysts is also predicted in the future. To place FAME on a comparative footing with fossil fuels requires progressive government plans and incentive schemes. Increasing the use of low-grade, or the waste oil as raw materials remains a challenge for existing solid catalysts. 


\section{Conclusions}

Increasing biodiesel utilization requires optimized processes of production that are compatible with high capacities of production and that feature high yields, simplified operations, and the lack of any special chemical treatments and waste streams. According to economic parameters, the high quality of the byproduct (glycerol) obtained is also very important. A catalyzed process allows all of these goals to be achieved. Using basic catalysts, the appropriate product (biodiesel) is produced at a favorable conversion rate. The performance of basic catalysts is more successful than any other catalysts, but the limitation for the use of basic catalysts is the existence of large amounts of FFAs and water in the raw materials. By using acidic catalysts, the limitations of basic catalysts can be overcome. A good conversion rate is attained even in the presence of large amounts of FFAs and water in the raw materials, but this conversion requires much time and, as the result, the cost of the reaction is higher. In recent years mainly homogeneous catalysts were used for biodiesel production, but now the development of efficient heterogeneous (solid) catalysts and biocatalysts opens the possibility of another pathway for the FAME production. The efficiency of the catalysts for the transesterification process depends on the alcohol-to-oil molar ratio, type of oil, catalyst type, temperature, and even the type of reactor.

Author Contributions: Conceptualization, M.A.H., U.R.; data curation, S.N., A.H.; writing-original draft preparation, S.N., M.N.A., A.H.; writing-review and editing, U.R., M.A.H., C.N.; visualization, M.A.H.; U.R.; supervision, M.A.H.; project administration, M.A.H., U.R. All authors have read and agreed to the published version of the manuscript.

Funding: Article Processing Charges (APC) were funded by Research Management Center (RMC), Universiti Putra Malaysia (UPM), Malaysia.

Institutional Review Board Statement: Not applicable.

Informed Consent Statement: Not applicable.

Data Availability Statement: Not applicable.

Conflicts of Interest: The authors declare no conflict of interest.

\section{References}

1. Cunningham, A.C. Revisiting Nuclear Power; Greenhaven Publishing LLC: New York, NY, USA, 2017.

2. Althor, G.; Watson, J.E.; Fuller, R.A. Global mismatch between greenhouse gas emissions and the burden of climate change. Sci. Rep. 2016, 6, 1-6. [CrossRef]

3. Mumtaz, M.W.; Adnan, A.; Anwar, F.; Mukhtar, H.; Raza, M.A.; Ahmad, F.; Rashid, U. Response surface methodology: An emphatic tool for optimized biodiesel production using rice bran and sunflower oils. Energies 2012, 5, 3307-3328. [CrossRef]

4. Ahmia, A.; Danane, F.; Bessah, R.; Boumesbah, I. Raw material for biodiesel production. Valorization of used edible oil. Rev. Des. Energ. Renouvelables 2014, 17, 335-343.

5. Konur, O. Biodiesel and Petrodiesel Fuels: Science, Technology, Health, and the Environment. In Biodiesel Fuels; CRC Press: Boca Raton, FL, USA, 2021; pp. 3-36.

6. ASTM D6751-20a Standard Specification for Biodiesel Fuel Blend Stock (B100) for Middle Distillate Fuels; ASTM International: West Conshohocken, PA, USA, 2014.

7. Hanif, M.A.; Nisar, S.; Akhtar, M.N.; Nisar, N.; Rashid, N. Optimized production and advanced assessment of biodiesel: A review. Int. J. Energy Res. 2018, 42, 2070-2083. [CrossRef]

8. Srivastava, R.; Singh, A.; Gaurav, K. Advancement in Catalysts for Transesterification in the Production of Biodiesel: A Review. J. Biochem. Technol. 2018, 7, 1148-1158.

9. Iqra, Y.; Umer, R.; Farwa, N. Alumina supported catalytic materials for biodiesel production-a detailed review. Int. J. Chem. Biochem. Sci. 2019, 16, 41-53.

10. Tacias-Pascacio, V.G.; Torrestiana-Sánchez, B.; Dal Magro, L.; Virgen-Ortíz, J.J.; Suárez-Ruíz, F.J.; Rodrigues, R.C.; Fernandez-Lafuente, R. Comparison of acid, basic and enzymatic catalysis on the production of biodiesel after RSM optimization. Renew. Energy 2019, 135, 1-9. [CrossRef]

11. Amoah, J.; Ho, S.-H.; Hama, S.; Yoshida, A.; Nakanishi, A.; Hasunuma, T.; Ogino, C.; Kondo, A. Converting oils high in phospholipids to biodiesel using immobilized Aspergillus oryzae whole-cell biocatalysts expressing Fusarium heterosporum lipase. Biochem. Eng. J. 2016, 105, 10-15. [CrossRef] 
12. Mansir, N.; Teo, S.H.; Rabiu, I.; Taufiq-Yap, Y.H. Effective biodiesel synthesis from waste cooking oil and biomass residue solid green catalyst. Chem. Eng. J. 2018, 347, 137-144. [CrossRef]

13. Rashid, U.; Soltani, S.; Al-Resayes, S.I.; Nehdi, I.A. Metal oxide catalysts for biodiesel production. In Metal Oxides in Energy Technologies; Elsevier: Amsterdam, The Netherlands, 2018; pp. 303-319.

14. Ambat, I.; Srivastava, V.; Sillanpää, M. Recent advancement in biodiesel production methodologies using various feedstock: A review. Renew. Sustain. Energy Rev. 2018, 90, 356-369. [CrossRef]

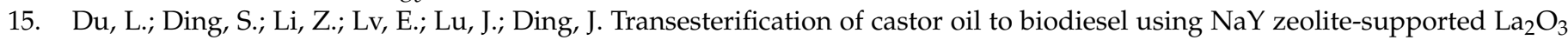
catalysts. Energy Convers. Manag. 2018, 173, 728-734. [CrossRef]

16. Gunstone, F.D. Supplies of vegetable oils for non-food purposes. Eur. J. Lipid Sci. Technol. 2011, 113, 3-7. [CrossRef]

17. Takács-György, K.; Lászlók, A.; Takács, I. Examination of first generation biofuel production in some selected biofuel producing countries in Europe: A case study. Agric. Econ. 2020, 66, 469-476. [CrossRef]

18. Lee, A.F.; Bennett, J.A.; Manayil, J.C.; Wilson, K. Heterogeneous catalysis for sustainable biodiesel production via esterification and transesterification. Chem. Soc. Rev. 2014, 43, 7887-7916. [CrossRef]

19. Dehkhoda, A.M.; West, A.H.; Ellis, N. Biochar based solid acid catalyst for biodiesel production. Appl. Catal. A Gen. 2010, 382, 197-204. [CrossRef]

20. Shahzadi, A.; Grondahl, L.; Nadeem, F. Development of effective composite supports for production of biodiesel-a detailed review. Int. J. Chem. Biochem. Sci. 2019, 16, 76-86.

21. Mehboob, A.; Nisar, S.; Rashid, U.; Choong, T.S.Y.; Khalid, T.; Qadeer, H.A. Reactor designs for the production of biodiesel. Int. J. Chem. Biochem. Sci. 2016, 10, 87-94.

22. Knothe, G.; Krahl, J.; Van Gerpen, J. The Biodiesel Handbook; Elsevier: Amsterdam, The Netherlands, 2015.

23. Ejikeme, P.; Anyaogu, I.; Ejikeme, C.; Nwafor, N.; Egbuonu, C.; Ukogu, K.; Ibemesi, J. Catalysis in biodiesel production by transesterification processes-an insight. J. Chem. 2010, 7, 1120-1132. [CrossRef]

24. Khurshid, S.N.A. Biodiesel Production by Using Heterogeneous Catalyst; IntechOpen: London, UK, 2014. [CrossRef]

25. Bora, L.; Bora, M. Optimization of extracellular thermophilic highly alkaline lipase from thermophilic Bacillus sp isolated from hotspring of Arunachal Pradesh, India. Braz. J. Microbiol. 2012, 43, 30-42. [CrossRef]

26. Gorji, A.; Ghanei, R. A review on catalytic biodiesel production. J. Biodivers. Environ. Sci. 2014, 5, 48-59.

27. Hossain, A.; Mazen, M. Effects of catalyst types and concentrations on biodiesel production from waste soybean oil biomass as renewable energy and environmental recycling process. Aust. J. Crop Sci. 2010, 4, 550.

28. Kartika, I.A.; Yani, M.; Ariono, D.; Evon, P.; Rigal, L. Biodiesel production from jatropha seeds: Solvent extraction and in situ transesterification in a single step. Fuel 2013, 106, 111-117. [CrossRef]

29. Dawodu, F.; Ayodele, O.; Bolanle-Ojo, T. Biodiesel production from Sesamum indicum L. seed oil: An optimization study. Egypt. J. Pet. 2014, 23, 191-199. [CrossRef]

30. Cao, H.; Zhang, Z.; Wu, X.; Miao, X. Direct biodiesel production from wet microalgae biomass of Chlorella pyrenoidosa through in situ transesterification. BioMed Res. Int. 2013, 2013, 930686. [CrossRef]

31. Sagiroglu, A.; Isbilir, S.Ş.; Ozcan, M.H.; Paluzar, H.; Toprakkiran, N.M. Comparison of biodiesel productivities of different vegetable oils by acidic catalysis. Chem. Ind. Chem. Eng. Q./CICEQ 2011, 17, 53-58. [CrossRef]

32. Chopade, S.G.; Kulkarni, K.; Kulkarni, A.; Topare, S. Solid heterogeneous catalysts for production of biodiesel from transesterification of triglycerides with methanol: A review. Acta Chim. Pharm. Indica 2012, 2, 8-14. [CrossRef]

33. Ramos, M.J.; Casas, A.; Rodríguez, L.; Romero, R.; Pérez, Á. Transesterification of sunflower oil over zeolites using different metal loading: A case of leaching and agglomeration studies. Appl. Catal. A Gen. 2008, 346, 79-85. [CrossRef]

34. Atadashi, I.; Aroua, M.; Aziz, A.A.; Sulaiman, N. The effects of catalysts in biodiesel production: A review. J. Ind. Eng. Chem. 2013, 19, 14-26. [CrossRef]

35. Muthu, H.; SathyaSelvabala, V.; Varathachary, T.; Kirupha Selvaraj, D.; Nandagopal, J.; Subramanian, S. Synthesis of biodiesel from Neem oil using sulfated zirconia via tranesterification. Braz. J. Chem. Eng. 2010, 27, 601-608. [CrossRef]

36. Shu, Q.; Gao, J.; Nawaz, Z.; Liao, Y.; Wang, D.; Wang, J. Synthesis of biodiesel from waste vegetable oil with large amounts of free fatty acids using a carbon-based solid acid catalyst. Appl. Energy 2010, 87, 2589-2596. [CrossRef]

37. Brucato, A.; Busciglio, A.; Di Stefano, F.; Grisafi, F.; Micale, G.; Scargiali, F. High temperature solid-catalized transesterification for biodiesel production. Chem. Eng. 2010, 19, 31-36.

38. Mo, X.; Lotero, E.; Lu, C.; Liu, Y.; Goodwin, J.G. A novel sulfonated carbon composite solid acid catalyst for biodiesel synthesis. Catal. Lett. 2008, 123, 1-6. [CrossRef]

39. Sani, Y.M.; Daud, W.M.A.W.; Aziz, A.A. Activity of solid acid catalysts for biodiesel production: A critical review. Appl. Catal. A Gen. 2014, 470, 140-161. [CrossRef]

40. Di Serio, M.; Cozzolino, M.; Tesser, R.; Patrono, P.; Pinzari, F.; Bonelli, B.; Santacesaria, E. Vanadyl phosphate catalysts in biodiesel production. Appl. Catal. A Gen. 2007, 320,1-7. [CrossRef]

41. Di Serio, M.; Ledda, M.; Cozzolino, M.; Minutillo, G.; Tesser, R.; Santacesaria, E. Transesterification of soybean oil to biodiesel by using heterogeneous basic catalysts. Ind. Eng. Chem. Res. 2006, 45, 3009-3014. [CrossRef]

42. Sunita, G.; Devassy, B.M.; Vinu, A.; Sawant, D.P.; Balasubramanian, V.; Halligudi, S. Synthesis of biodiesel over zirconia-supported isopoly and heteropoly tungstate catalysts. Catal. Commun. 2008, 9, 696-702. [CrossRef] 
43. Patel, R.L.; Sankhavara, C. Biodiesel production from Karanja oil and its use in diesel engine: A review. Renew. Sustain. Energy Rev. 2017, 71, 464-474. [CrossRef]

44. Canakci, M.; Van Gerpen, J. Biodiesel production viaacid catalysis. Trans. ASAE 1999, 42, 1203. [CrossRef]

45. Thanh, L.T.; Okitsu, K.; Boi, L.V.; Maeda, Y. Catalytic technologies for biodiesel fuel production and utilization of glycerol: A review. Catalysts 2012, 2, 191-222. [CrossRef]

46. Takemoto, M.; Tokudome, Y.; Murata, H.; Okada, K.; Takahashi, M.; Nakahira, A. Synthesis of high-specific-surface-area Li-Al mixed metal oxide: Through nanoseed-assisted growth of layered double hydroxide. Appl. Clay Sci. 2021, 203, 106006. [CrossRef]

47. Meng, X.; Chen, G.; Wang, Y. Biodiesel production from waste cooking oil via alkali catalyst and its engine test. Fuel Process. Technol. 2008, 89, 851-857. [CrossRef]

48. Gok, H.Y. Development of Sodium Alkoside Catalysts from Polyols. Ph.D. Thesis, University of Saskatchewan, Saskatoon, SK, Canada, 2011.

49. Mathew, G.M.; Raina, D.; Narisetty, V.; Kumar, V.; Saran, S.; Pugazhendi, A.; Sindhu, R.; Pandey, A.; Binod, P. Recent advances in biodiesel production: Challenges and solutions. Sci. Total Environ. 2021, 794, 148751. [CrossRef] [PubMed]

50. Ruwwe, J. Metal alkoxides as catalysts for the biodiesel production. Chim. Oggi 2008, 26, 26.

51. Baskar, G.; Aiswarya, R. Trends in catalytic production of biodiesel from various feedstocks. Renew. Sustain. Energy Rev. 2016, 57, 496-504. [CrossRef]

52. Prafulla, D.P.; Veera Gnaneswar, G.; Harvind, K.R.; Tapaswy, M.; Shuguang, D. Biodiesel production from waste cooking oil using sulfuric acid and microwave irradiation processes. J. Environ. Prot. 2012, 2012. [CrossRef]

53. Xie, W.; Wang, H. Grafting copolymerization of dual acidic ionic liquid on core-shell structured magnetic silica: A magnetically recyclable Brönsted acid catalyst for biodiesel production by one-pot transformation of low-quality oils. Fuel 2021, 283, 118893. [CrossRef]

54. Suwannakarn, K. Biodiesel Production from High Free Fatty Acid Content Feedstocks. Ph.D. Thesis, Clemson University, Clemson, SC, USA, 2008.

55. Nugraha, R.E.; Prasetyoko, D.; Bahruji, H.; Suprapto, S.; Asikin-Mijan, N.; Oetami, T.P.; Jalil, A.A.; Vo, D.-V.N.; Taufiq-Yap, Y.H. Lewis acid Ni/Al-MCM-41 catalysts for H 2-free deoxygenation of Reutealis trisperma oil to biofuels. RSC Adv. 2021, 11, 21885-21896. [CrossRef]

56. Ma, F.; Hanna, M.A. Biodiesel production: A review. Bioresour. Technol. 1999, 70, 1-15. [CrossRef]

57. Farobie, O.; Yanagida, T.; Matsumura, Y. New approach of catalyst-free biodiesel production from canola oil in supercritical tert-butyl methyl ether (MTBE). Fuel 2014, 135, 172-181. [CrossRef]

58. de Lima, A.L.; Ronconi, C.M.; Mota, C.J. Heterogeneous basic catalysts for biodiesel production. Catal. Sci. Technol. 2016, 6, 2877-2891. [CrossRef]

59. Verma, P.; Sharma, M.; Dwivedi, G. Impact of alcohol on biodiesel production and properties. Renew. Sustain. Energy Rev. 2016, 56, 319-333. [CrossRef]

60. Endalew, A.K.; Kiros, Y.; Zanzi, R. Heterogeneous catalysis for biodiesel production from Jatropha curcas oil (JCO). Energy 2011, 36, 2693-2700. [CrossRef]

61. Bharti, M.K.; Chalia, S.; Thakur, P.; Sridhara, S.; Thakur, A.; Sharma, P. Nanoferrites heterogeneous catalysts for biodiesel production from soybean and canola oil: A review. Environ. Chem. Lett. 2021. [CrossRef]

62. Romero, R.; Natividad, R.; Martínez, S.L. Biodiesel Production by Using Heterogeneous Catalysts; INTECH Open Access Publisher: London, UK, 2011.

63. Jayakumar, M.; Karmegam, N.; Gundupalli, M.P.; Gebeyehu, K.B.; Asfaw, B.T.; Chang, S.W.; Balasubramani, R.; Awasthi, M.K. Heterogeneous base catalysts: Synthesis and application for biodiesel production-A review. Bioresour. Technol. 2021, $2021,125054$. [CrossRef] [PubMed]

64. Lam, M.K.; Lee, K.T.; Mohamed, A.R. Homogeneous, heterogeneous and enzymatic catalysis for transesterification of high free fatty acid oil (waste cooking oil) to biodiesel: A review. Biotechnol. Adv. 2010, 28, 500-518. [CrossRef] [PubMed]

65. Yoo, S.J.; Lee, H.-S.; Veriansyah, B.; Kim, J.; Kim, J.-D.; Lee, Y.-W. Synthesis of biodiesel from rapeseed oil using supercritical methanol with metal oxide catalysts. Bioresour. Technol. 2010, 101, 8686-8689. [CrossRef]

66. Esposito, R.; Melchiorre, M.; Annunziata, A.; Cucciolito, M.E.; Ruffo, F. Emerging catalysis in biomass valorisation: Simple Zn (II) catalysts for fatty acids esterification and transesterification. ChemCatChem 2020, 12, 5858-5879. [CrossRef]

67. Ooi, H.K.; Koh, X.N.; Ong, H.C.; Lee, H.V.; Mastuli, M.S.; Taufiq-Yap, Y.H.; Alharthi, F.A.; Alghamdi, A.A.; Asikin Mijan, N. Progress on Modified Calcium Oxide Derived Waste-Shell Catalysts for Biodiesel Production. Catalysts 2021, 11, 194. [CrossRef]

68. Tavizón-Pozos, J.A.; Chavez-Esquivel, G.; Suárez-Toriello, V.A.; Santolalla-Vargas, C.E.; Luévano-Rivas, O.A.; Valdés-Martínez, O.U.; Talavera-López, A.; Rodriguez, J.A. State of art of alkaline earth metal oxides catalysts used in the transesterification of oils for biodiesel production. Energies 2021, 14, 1031. [CrossRef]

69. Kesić, Ž.; Lukić, I.; Zdujić, M.; Mojović, L.; Skala, D. Calcium oxide based catalysts for biodiesel production: A review. Chem. Ind. Chem. Eng. Q. 2016, 22, 10. [CrossRef]

70. Yusuff, A.S.; Kumar, M.; Obe, B.O.; Mudashiru, L.O. Calcium Oxide Supported on Coal Fly Ash (CaO/CFA) as an Efficient Catalyst for Biodiesel Production from Jatropha curcas Oil. Top. Catal. 2021, 1-13. [CrossRef]

71. Buasri, A.; Rattanapan, T.; Boonrin, C.; Wechayan, C.; Loryuenyong, V. Oyster and Pyramidella shells as heterogeneous catalysts for the microwave-assisted biodiesel production from Jatropha curcas oil. J. Chem. 2015, 2015, 578625. [CrossRef] 
72. Kouzu, M.; Kasuno, T.; Tajika, M.; Yamanaka, S.; Hidaka, J. Active phase of calcium oxide used as solid base catalyst for transesterification of soybean oil with refluxing methanol. Appl. Catal. A Gen. 2008, 334, 357-365. [CrossRef]

73. Kazembe-Phiri, H.; Matsumura, Y.; Minowa, T. New approaches to biodiesel production by ethanolysis with calcium hydroxide catalyst using thermal pretreatment with glycerol. J. Japan Inst. Energy 2010, 89, 562-566. [CrossRef]

74. Hawash, S.; El Diwani, G.; Abdel Kader, E. Optimization of biodiesel production from Jatropha oil by heterogeneous base catalysed transesterification. Int. J. Eng. Sci. Technol. 2011, 3, 5242-5251.

75. Granados, M.L.; Poves, M.Z.; Alonso, D.M.; Mariscal, R.; Galisteo, F.C.; Moreno-Tost, R.; Santamaría, J.; Fierro, J. Biodiesel from sunflower oil by using activated calcium oxide. Appl. Catal. B Environ. 2007, 73, 317-326. [CrossRef]

76. Xie, W.; Peng, H.; Chen, L. Calcined Mg-Al hydrotalcites as solid base catalysts for methanolysis of soybean oil. J. Mol. Catal. A Chem. 2006, 246, 24-32. [CrossRef]

77. Castanheiro, J. Heterogeneous Acid Catalysts for Biodiesel Production from Waste Cooking Oil. In Biodiesel Fuels Based on Edible and Nonedible Feedstocks, Wastes, and Algae; CRC Press: Boca Raton, FL, USA, 2021; pp. 643-649.

78. Jacobson, K.; Gopinath, R.; Meher, L.C.; Dalai, A.K. Solid acid catalyzed biodiesel production from waste cooking oil. Appl. Catal. B Environ. 2008, 85, 86-91. [CrossRef]

79. Afsharizadeh, M.; Mohsennia, M. Novel rare-earth metal oxides-zirconia nanocatalysts for biodiesel production from corn oil and waste cooking oil. Fuel 2021, 304, 121350. [CrossRef]

80. Macedo, C.; Abreu, F.R.; Tavares, A.P.; Alves, M.B.; Zara, L.F.; Rubim, J.C.; Suarez, P.A. New heterogeneous metal-oxides based catalyst for vegetable oil trans-esterification. J. Braz. Chem. Soc. 2006, 17, 1291-1296. [CrossRef]

81. Babu, N.S.; Sree, R.; Prasad, P.S.; Lingaiah, N. Room-temperature transesterification of edible and nonedible oils using a heterogeneous strong basic Mg/La catalyst. Energy Fuels 2008, 22, 1965-1971. [CrossRef]

82. Yan, S.; Lu, H.; Liang, B. Supported $\mathrm{CaO}$ catalysts used in the transesterification of rapeseed oil for the purpose of biodiesel production. Energy Fuels 2007, 22, 646-651. [CrossRef]

83. Lee, D.-W.; Park, Y.-M.; Lee, K.-Y. Heterogeneous base catalysts for transesterification in biodiesel synthesis. Catal. Surv. Asia 2009, 13, 63-77. [CrossRef]

84. Alaba, P.A.; Sani, Y.M.; Daud, W.M.A.W. Efficient biodiesel production via solid superacid catalysis: A critical review on recent breakthrough. RSC Adv. 2016, 6, 78351-78368. [CrossRef]

85. Đặng, T.-H.; Nguyễn, X.-H.; Chou, C.-L.; Chen, B.-H. Preparation of cancrinite-type zeolite from diatomaceous earth as transesterification catalysts for biodiesel production. Renew. Energy 2021, 174, 347-358. [CrossRef]

86. Suppes, G.J.; Dasari, M.A.; Doskocil, E.J.; Mankidy, P.J.; Goff, M.J. Transesterification of soybean oil with zeolite and metal catalysts. Appl. Catal. A Gen. 2004, 257, 213-223. [CrossRef]

87. Vyas, A.P.; Subrahmanyam, N.; Patel, P.A. Production of biodiesel through transesterification of Jatropha oil using $\mathrm{KNO}_{3} / \mathrm{Al}_{2} \mathrm{O}_{3}$ solid catalyst. Fuel 2009, 88, 625-628. [CrossRef]

88. Bo, X.; Guomin, X.; Lingfeng, C.; Ruiping, W.; Lijing, G. Transesterification of palm oil with methanol to biodiesel over a $\mathrm{KF} / \mathrm{Al}_{2} \mathrm{O}_{3}$ heterogeneous base catalyst. Energy Fuels 2007, 21, 3109-3112. [CrossRef]

89. D'Cruz, A.; Kulkarni, M.G.; Meher, L.C.; Dalai, A.K. Synthesis of biodiesel from canola oil using heterogeneous base catalyst. J. Am. Oil Chem. Soc. 2007, 84, 937-943. [CrossRef]

90. Xie, W.; Li, H. Alumina-supported potassium iodide as a heterogeneous catalyst for biodiesel production from soybean oil. J. Mol. Catal. A Chem. 2006, 255, 1-9. [CrossRef]

91. Dahdah, E.; Estephane, J.; Taleb, Y.; El Khoury, B.; El Nakat, J.; Aouad, S. The role of rehydration in enhancing the basic properties of Mg-Al hydrotalcites for biodiesel production. Sustain. Chem. Pharm. 2021, 22, 100487. [CrossRef]

92. Said, N.; Ani, F.; Said, M. Review of the production of biodiesel from waste cooking oil using solid catalysts. J. Mech. Eng. Sci. 2015, 8, 1302-1311. [CrossRef]

93. Pathak, S. Acid catalyzed transesterification. J. Chem. Pharm. Res. 2015, 7, 1780-1786.

94. Naik, B.D.; Udayakumar, M. Optimization studies on esterification of waste cooking oil using sulfated montmorillonite clay acidic catalyst. Mater. Today Proc. 2021. [CrossRef]

95. Hanif, M.A.; Nisar, S.; Rashid, U. Supported solid and heteropoly acid catalysts for production of biodiesel. Catal. Rev. 2017, 59, 165-188. [CrossRef]

96. Zeng, D.; Liu, S.; Gong, W.; Wang, G.; Qiu, J.; Chen, H. Synthesis, characterization and acid catalysis of solid acid from peanut shell. Appl. Catal. A Gen. 2014, 469, 284-289. [CrossRef]

97. Diamantopoulos, N.; Panagiotaras, D.; Nikolopoulos, D. Comprehensive Review on the Biodiesel Production using Solid Acid Heterogeneous Catalysts. J. Thermodyn. Catal. 2015, 6, 1. [CrossRef]

98. Hillion, G.; Delfort, B.; le Pennec, D.; Bournay, L.; Chodorge, J.-A. Biodiesel production by a continuous process using a heterogeneous catalyst. Prepr. Pap.-Am. Chem. Soc. Div. Fuel Chem. 2003, 48, 636.

99. Bobade, V.; Kulkarni, K.; Kulkarni, A. Application of Heterogeneous Catalyst for the Production of Biodiesel. Int. J. Adv. Eng. Technol. 2011, 2, 184-185.

100. Hama, S.; Noda, H.; Kondo, A. How lipase technology contributes to evolution of biodiesel production using multiple feedstocks. Curr. Opin. Biotechnol. 2018, 50, 57-64. [CrossRef] [PubMed]

101. Mittelbach, M. Fuels from oils and fats: Recent developments and perspectives. Eur. J. Lipid Sci. Technol. 2015, 117, 1832-1846. [CrossRef] 
102. Sankaran, R.; Show, P.L.; Chang, J.S. Biodiesel production using immobilized lipase: Feasibility and challenges. Biofuels Bioprod. Biorefin. 2016, 10, 896-916. [CrossRef]

103. Hama, S.; Kondo, A. Enzymatic biodiesel production: An overview of potential feedstocks and process development. Bioresour. Technol. 2013, 135, 386-395. [CrossRef] [PubMed]

104. Cesarini, S.; Pastor, F.; Nielsen, P.; Diaz, P. Moving towards a competitive fully enzymatic biodiesel process. Sustainability 2015, 7, 7884-7903. [CrossRef]

105. Amoah, J.; Ho, S.-H.; Hama, S.; Yoshida, A.; Nakanishi, A.; Hasunuma, T.; Ogino, C.; Kondo, A. Lipase cocktail for efficient conversion of oils containing phospholipids to biodiesel. Bioresour. Technol. 2016, 211, 224-230. [CrossRef]

106. Sahoo, R.K.; Kumar, M.; Sukla, L.B.; Subudhi, E. Bioprospecting hot spring metagenome: Lipase for the production of biodiesel. Environ. Sci. Pollut. Res. 2017, 24, 3802-3809. [CrossRef]

107. Dias, G.S.; de Lima Luz, L.F., Jr.; Mitchell, D.A.; Krieger, N. Scale-up of biodiesel synthesis in a closed-loop packed-bed bioreactor system using the fermented solid produced by Burkholderia lata LTEB11. Chem. Eng. J. 2017, 316, 341-349. [CrossRef] 